\title{
Revision of the late Pleistocene stratigraphy of Bermuda
}

\author{
Paul J. Hearty* \\ School of Earth Sciences, James Cook University, Townsville QLD 4811, Australia
}

Received 4 July 2001; accepted 31 May 2002

\begin{abstract}
The Quaternary stratigraphy of Bermuda is one of the world's most complete sedimentary records of interglacial highstands, representing at least the past million years. Yet in terms of the last interglacial (Rocky Bay Formation), marine isotope substage (MIS) 5e, only scanty deposits are preserved. In contrast, MIS 7, generally regarded as a diminutive interglaciation, exposes widespread emergent subtidal deposits of the Belmont Formation indicating a prolonged sea level highstand at ca. $+2.5 \pm 0.3$ m. This "Belmont paradox" has prompted a reexamination of the geology of key sites along the South Shore of Bermuda.

This revision of the late Quaternary stratigraphy of Bermuda is based on geological field observations; primarily the questionable origin of red soil-like deposits. It is concluded here that there is no physical evidence of the exposure of the upper Belmont surface for a full glacial cycle $(\sim 70-100 \mathrm{ka})$, and that interbedded, reddish soil-like, lenticular deposits are the result of colluvial activity during mid-MIS 5e. Reexamination of previously published uranium-series (U/Th) ages indicates that several " +3-m notches" contain a mix of ca. $125 \mathrm{ka}$ and older coral ages. Contrary to previous works, this study favors an early MIS 5e interpretation of the coral ages from the +2.5 -m Belmont shoreline, which is further supported by amino acid racemization (AAR) ratios on whole-rock, Poecilozonites, Glycymeris, and Brachiodontes samples from shore and notch deposits. An updated AAR kinetic model demonstrates that the bulk of epimerization occurred during warm interglacial intervals between 130 and $80 \mathrm{ka}$ and the last $10 \mathrm{ka}$ of the Holocene. This revised stratigraphy of Bermuda now falls into accordance with a more general view of middle and late Pleistocene sea level history.
\end{abstract}

(c) 2002 Elsevier Science B.V. All rights reserved.

Keywords: Bermuda; Sea-level history; Late Pleistocene; Marine isotope substage 5e; Quaternary stratigraphy; Amino acid geochronology

\section{Introduction}

In a global context, Bermuda (Fig. 1) has been regarded as a "tide gauge" (Land et al., 1967) or oceanic "dipstick" of sea level changes during the Quaternary. However, rather than demonstrating the sea level rule, Bermuda has been more the exception to it. Marine isotope substage (MIS) $5 \mathrm{e}$ is considered

\footnotetext{
* Tel.: +61-74-7815283.

E-mail address: paul.hearty@jcu.edu.au (P.J. Hearty).
}

by many authors to have been an important sea-level highstand impacting most of the world's stable coastlines (Hearty, 1986; Murray-Wallace and Belperio, 1991; Neumann and Hearty, 1996). Yet on Bermuda's South Shore, MIS 5e deposits are patchy and poorly represented. In contrast, MIS 7 outcrops extensively as subtidal deposits (Vacher et al., 1989), even though a relatively minor interglacial highstand is suggested by deep-sea oxygen isotope records (Shackleton and Opdyke, 1973; Shackleton et al., 1990; Chappell and Shackelton, 1986). 


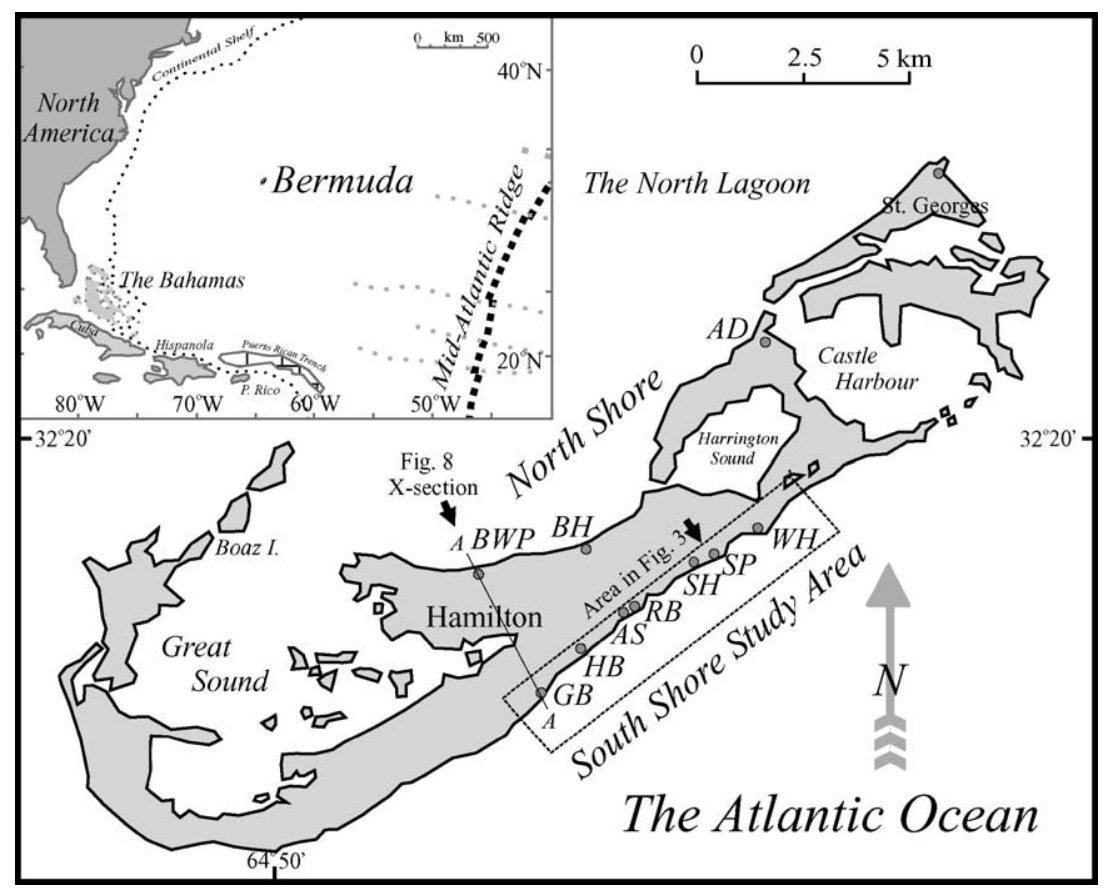

Fig. 1. Location of Bermuda in the central north Atlantic abyssal plain, and study sites discussed in the text. Explanation of abbreviations: $\mathrm{GB}=$ Grape Bay, $\mathrm{HB}=$ Hungry Bay, $\mathrm{AS}=$ Ariel Sands, $\mathrm{RB}=$ Rocky Bay, $\mathrm{SH}=$ Saucos Hill, $\mathrm{SP}=$ Spittal Pond, WH=Watch Hill Park, $\mathrm{AD}=$ Admiral's Cave, $\mathrm{BH}=$ Barker's Hill, and BWP=Blackwatch Pass. A " $\mathrm{U}$ " for Bermuda is added to each of the site names in the following figures and text.

\subsection{Stratigraphic setting of the Belmont and Rocky Bay formations}

The stratigraphic column of Bermuda (Table 1) consists of six major limestone units bracketed by terra rossa paleosols. This column has evolved considerably since Bretz (1960) identified three formations (Devoynshire, Belmont, and Walsingham). According to Bretz, the "Belmont" should encompass all rock units between the last interglaciation and the early Pleistocene, which comprise most of "Older Bermuda". Land et al. (1967) and Harmon et al. (1983) further modified the stratigraphic column.

Vacher et al. (1989) chose South Shore sections for type localities, which they felt more appropriately illustrated the stratigraphic relationships between Belmont and Rocky Bay formations. The classic type locality of the Belmont Formation (Bretz, 1960) at the Belmont Pier was later redefined as Town Hill Formation (Table 1). Hearty et al. (1992) adopted Vacher et al.'s (1989) stratigraphy, adding two additional "unnamed" units. These consist of an eolianite and protosol at the base of Blackwatch Pass, and a +22-m marine deposit at Government Quarry (Land et al., 1967), which correlates with MIS 11 (Hearty et al., 1999).

The South Shore best represents "Younger Bermuda" that, according to previous studies (Bretz, 1960; Land et al., 1967), includes deposits of late and late-middle Pleistocene interglaciations. Belmont, Rocky Bay, and Southampton Formations occur in succession (Vacher et al., 1989) along the South Shore (Table 1). The Belmont Formation, regarded as part of MIS 7, contains marine ( $\mathrm{Bm}$ ) and eolian $(\mathrm{Be})$ facies, or multiple units of each (Meischner et al., 1995). The Rocky Bay Formation was subdivided from base to top into the Devonshire marine (Dm), the Harrington protosol (Hp) (sensu Vacher and Hearty, 1989), and the Pembroke eolianite $(\mathrm{Pe})$ members. The units comprising the Rocky Bay Formation are indicative of a relatively complex MIS 5e interglaciation. The 
Table 1

Correlation table of nomenclature associated with the stratigraphy of Bermuda

\begin{tabular}{|c|c|c|c|}
\hline Land et al. (1967) & $\begin{array}{l}\text { Vacher et al. }(1989,1995) \text {; } \\
\text { Hearty et al. (1992) }\end{array}$ & This study & $\begin{array}{l}\text { Correlated marine oxygen } \\
\text { isotope stage (MIS) }\end{array}$ \\
\hline Recent & Recent & Recent & 1 \\
\hline $\begin{array}{l}\text { St. Georges soil, } \\
\text { Spencer's Point }\end{array}$ & St. Georges soil & $\begin{array}{l}\text { Admiral's cave talus, } \\
\text { St. Georges soil }\end{array}$ & 1 to $5 \mathrm{e}$ \\
\hline \multirow[t]{3}{*}{ Southampton Fm } & \multirow[t]{3}{*}{ Southampton Fm } & Southampton Fm & $5 \mathrm{a}$ \\
\hline & & $\begin{array}{l}\text { Former Pembroke } \mathrm{Mb}(\mathrm{Pe}) \text {, } \\
\text { new name: Hungry Bay Fm }\end{array}$ & $5 \mathrm{c}$ \\
\hline & & Harrington $\mathrm{Mb}(\mathrm{Hp})$, palaeosol & $5 e / 5 c$ \\
\hline \multirow[t]{3}{*}{$\begin{array}{l}\text { Pembroke formation, } \\
\text { Harrington soil, } \\
\text { Devonshire formation }\end{array}$} & \multirow[t]{3}{*}{$\begin{array}{l}\text { Rocky Bay Fm, } \\
\text { Pembroke } \mathrm{Mb}, \\
\text { Harrington } \mathrm{Mb}, \\
\text { Devonshire } \mathrm{Mb}\end{array}$} & $\begin{array}{l}\text { Rocky Bay Fm, } \\
\text { Devonshire Mb }(\mathrm{Dm}) \text {, } \\
\text { primarily marine, } \\
\text { (sea level at }+6-9 \mathrm{~m}) \text {, } \\
\text { Watch Hill Park and Spencer's Pt. }\end{array}$ & Late $5 \mathrm{e}$ \\
\hline & & $\begin{array}{l}\text { Minor mid-5e regression; } \\
\text { red colluvium (rc) }\end{array}$ & Middle $5 \mathrm{e}$ \\
\hline & & $\begin{array}{l}\text { Former Belmont } \mathrm{Fm}(\mathrm{Bm} / \mathrm{Be}) \\
\text { (subtidal to dune; } \\
\text { sea level at }+2.5 \mathrm{~m}), \\
\text { new name: Grape Bay } \mathrm{Mb} \text { of } \\
\text { Rock Bay Fm }\end{array}$ & Early 5e \\
\hline Shore Hills soil & Shore Hills geosol & Red geosol (?) & 6 \\
\hline \multirow[t]{6}{*}{ Belmont formation } & $\begin{array}{l}\text { Belmont Fm, } \\
\text { marine and dune }(+2.5 \mathrm{~m})\end{array}$ & $\begin{array}{l}\text { Harvey Rd, } \\
\text { Quarry, Eolianite? }\end{array}$ & 7 \\
\hline & Ord Rd. Geosol & Ord Rd. Geosol & 8 \\
\hline & Upper Town Hill Mb/Fm & Upper Town Hill Fm & 9 \\
\hline & Lower Town Hill Mb/Fm & Lower Town Hill Fm, +20-m highstand & 11 \\
\hline & Unnamed unit? & "Big Red Soil” & $12-26 ?$ \\
\hline & Castle Harbour geosol & & \\
\hline Walsingham Fm & Walsingham Fm & Walsingham Fm & $27 / 35 ?$ \\
\hline
\end{tabular}

younger Southampton Formation is represented primarily by eolianites, but Vacher and Hearty (1989) described and correlated marine deposits near present sea level with MIS 5a at around $80 \mathrm{ka}$. Their correlation with MIS 5a was later confirmed by thermal ionization mass spectrometry (TIMS) uranium-series dating (Ludwig et al., 1996). Unlike the Bahamas (Hearty and Kindler, 1993; Hearty and Kaufman, 2000), middle and late Holocene deposits (MIS 1) are poorly represented in Bermuda: modern beaches and dunes are the primary deposits of this interval.

\subsection{Previous grounds for a Belmont=MIS 7 inter- pretation}

Previous MIS 7 interpretations of the Belmont were based on: (1) the presence of two distinct marine units $(\mathrm{Bm}$ and $\mathrm{Dm})$ in South Shore sections; (2) the greater induration of the lower $(\mathrm{Bm})$ of the two units; (3) the localized interbedding of red, soil-like deposits among these marine units; and (4) the apparent support offered by several ca. 200 ka U/Th ages on corals from emergent marine deposits. 
Accepting the accuracy of Vacher et al.'s (1989) mapping, Hearty et al. (1992) utilized Bermuda's stratigraphy as a means to test and evaluate the AAR method. From this comparison, they demonstrated agreement with stratigraphic order in 97\% of the test cases, and independently confirmed the stratigraphic succession. The Rocky Bay and Belmont Formations were thus correlated with MIS 5e and 7, respectively (Hearty et al., 1992). Other studies such as Vollbrecht (1990) and Meischner et al. (1995) embraced this preliminary geochronological scheme.

\subsection{Difficulties associated with MIS 7 age interpre- tation of the Belmont formation}

The study of late Quaternary stratigraphy over the past several years has raised several fundamental questions. These questions are not about the stratigraphic succession of the interglacial deposits in Bermuda. This is not in dispute. The primary focus of this study is the interpretation of the age and correlation of the Belmont and Devonshire marine units with MIS 7 and/or 5e (Fig. 2). When viewed in a global perspective of sea level history, several specific problems associated with the late Pleistocene stratigraphy of Bermuda arise.
(1) The MIS 5e deposits that typically dominate moderate to high energy, relatively stable coastlines of the world are conspicuously lacking from much of the low-profile South Shore between Grape Bay and Watch Hill Park (Fig. 1). The geological map of Vacher et al. (1989) reveals only small, isolated patches of MIS 5e marine deposits at a few places, including the type locality at Devonshire Bay and Rocky Bay (Fig. 3). Indeed, the Pembroke eolianite comprises the greatest volume of the Rocky Bay Formation.

(2) The geologic map indicates that deposits of the Belmont Formation, correlated with MIS 7, are most common along this reach of coastline.

(3) The deep-sea oxygen isotope record (Fig. 2) magnifies the MIS 7-Belmont paradox-Substage 5e was one of the two warmest interglacials of the past half million years, while Stage 7 was one of the coolest (Shackleton et al., 1990). The oxygen isotope record suggests MIS 5e sea levels should have been significantly higher than present, while those from MIS 7 should have been lower than present.

\subsection{Reexamination of the stratigraphy of Bermuda's south shore}

The primary hypotheses of this paper are firstly, that the Belmont Formation, previously correlated

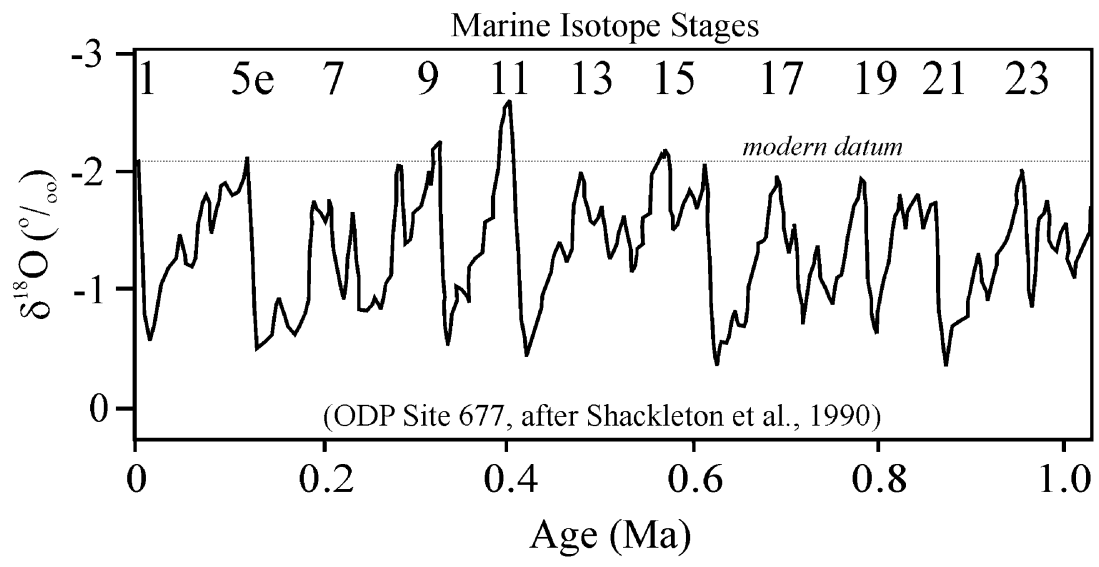

Fig. 2. Oxygen isotope curve of Core 677 based on planktonic foraminifera (Shackleton et al., 1990) showing the relative $\delta^{18} 0$ intensities of MIS 5e and MIS 7 interglacials. This relationship is typical for most records of these two interglaciations. The deep-sea oxygen isotope record generally implies that MIS 7 was one of the coolest and lowest interglacial sea levels of the past half million years. Coastal records from Oahu, HI (Sherman et al., 1999) and Italy (Bard et al., 2002) confirm that late MIS 7 sea level stood between -10 and $-20 \mathrm{~m}$. 

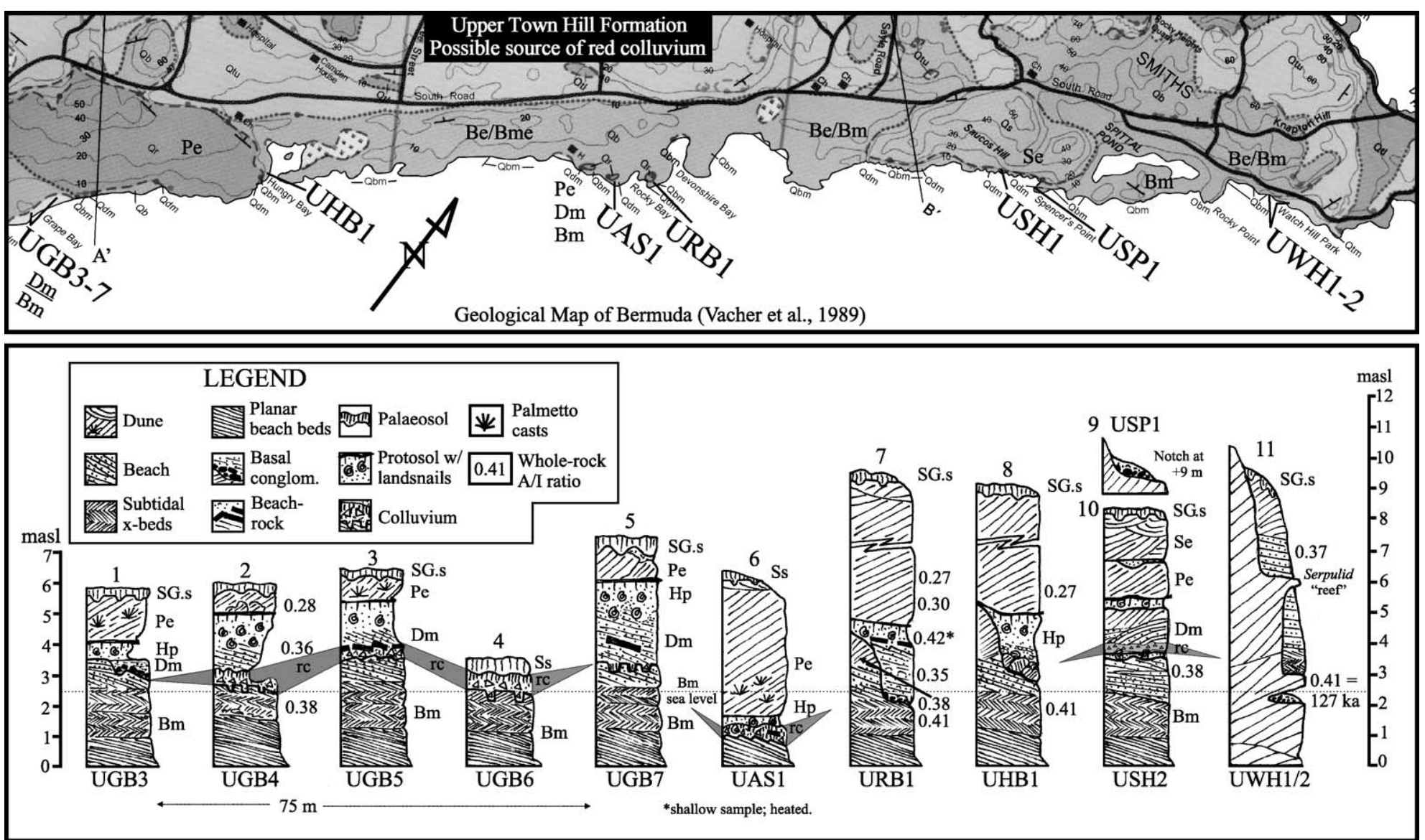

Fig. 3. Eleven stratigraphic sections between Grape Bay and Watch Hill Park showing the key units discussed in this study (see Fig. 1 for locations). Whole-rock $A / I$ ratios are included in the sections. Approximate elevation of Belmont $(\mathrm{Bm})$ sea level indicated by dashed horizontal line at $+2.5 \mathrm{~m}$. Abbreviations: Bm $=$ Belmont marine; Be $=$ Belmont eolianite; rc=red colluvium; $\mathrm{Dm}=$ Devonshire marine; $\mathrm{Hp}=$ Harrington protosol; $\mathrm{Pe}=$ Pembroke eolianite; SG.s = St. Georges Soil. 
with MIS 7 (235 to $190 \mathrm{ka}$ ), was formed during early MIS 5e (132 to $\sim 125 \mathrm{ka})$. And secondly, that the "Pembroke" dune, generally regarded as a regressive eolian facies of MIS 5e, was deposited during a postMIS 5e rise of sea level. To evaluate these hypotheses, the following sedimentological and geochronological aspects will be considered.

(1) The stratigraphic succession and eustatic significance of the major marine units along the South Shore of Bermuda.

(2) The origin of the blonde to red "soil-like units" and their respective contacts and unconformities in the Belmont-Rocky Bay sequence. Were they formed as: (a) full glacial paleosols; (b) midinterglacial paleosols; (c) mid-interglacial "protosols" (sensu Vacher and Hearty, 1989) or entisols; or (d) nonpedogenic, alluvial, or colluvial red soillike slope wash deposits? Red palaeosols commonly mantle older Pleistocene hillsides near the study area and around Bermuda.

(3) Existing and new geochronological data relevant to these hypotheses. These data include previously published U/Th ages, and over 300 published and new AAR ratios.

\section{South Shore geology, major stratigraphic units, and key sites}

\subsection{Highstand units and sea level estimates}

The locations of 11 sections are shown in Fig. 1 and are logged in Fig. 3, along with a segment of the geologic map of Vacher et al. (1989). They represent most of Younger Bermuda's key sections from both a historical perspective, and those most relevant to the discussions in this paper. The geologic map (Fig. 3) shows the surficial distribution of the Belmont (blue) and Rocky Bay (green) formations and is a faithful representation of the outcrop areas of both units.

Diverse shoreline facies are recognized among the sites, which are richly represented at Grape Bay (Fig. 4). Eolianites are viewed as a landward facies of the beach and subtidal zones (Bretz, 1960; Land et al., 1967). Palaeo-sea level is marked by the transition from subtidal to intertidal sedimentary structures. Corals used in dating studies are generally restricted to cobbles in marine sands and conglomerates (Fig. $3)$. It is well recognized that these coral cobbles may be reworked within and between sea level cycles (i.e.,

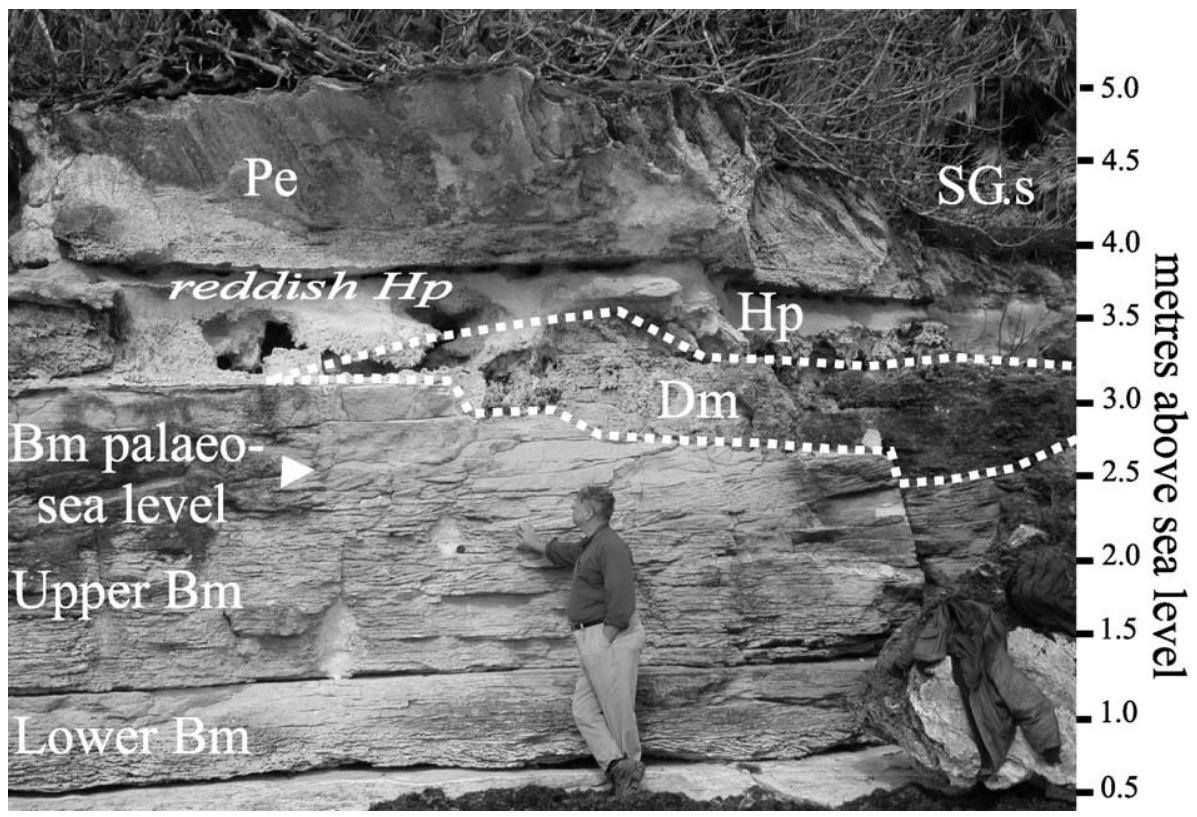

Fig. 4. Typical shoreline facies of the Rocky Bay and Belmont formations at Grape Bay Section 1 (UGB3). Abbreviations as in Fig. 3. A paleosea level at $+2.5 \mathrm{~m}$, indicated by the transition from subtidal herringbone bedding to planar beach bedding, is noted in the photo. 
highstand to highstand, or lowstand to highstand). However, as Bermuda at $32^{\circ}$ north latitude is already at the northern limit of coral growth in the Atlantic, it is unlikely that any reef coral thrived during glacial lowstands of sea level. Emergent and in situ reefs are uncharacteristic of Bermuda (Rowe, 1998), thus U/Th ages from reworked coral cobbles present important implications for chronologies of Bermuda. That is, only the youngest in a set of U-series ages derived from coral cobbles in a deposit most nearly approximates the true age of the deposit.

\subsubsection{Belmont marine (Bm) and eolian (Be) deposits}

$\mathrm{Bm}$ planar beach beds or beach rock indicate an early rise of sea level to just above present $(\sim+1 \mathrm{~m})$. A Bm stillstand was measured at $+2.5 \pm 0.3 \mathrm{~m}$ in nine sections for this study (Fig. 3). Meischner et al. (1995) described a complex history of the sea-level events during Belmont time, primarily based on outcrops at Grape Bay and Watch Hill Park. Their view includes at least two minor highstand cycles interpreted from "Belmont" deposits that were accepted from previous studies as MIS 7 age.

The $\mathrm{Bm}$ is distinguished from the Dm by finer texture and sorting, more detailed preservation of bedding, and a greater degree of cementation below about $+2 \mathrm{~m}$. The $\mathrm{Bm}$ grades upward and landward into moderately to loosely cemented sands (then $\mathrm{Be}$ ). Colored bioclasts, such as Homotrema rubrum and Brachiodontes exustus, reflect the near-pristine mineralogy of both $\mathrm{Bm}$ and Dm units. Meischner et al. (1995) explained the greater induration of the lower Bm by an advanced level of marine phreatic diagenesis, followed by a generation of meteoric (vadose) alteration, and a later high-Mg calcite cement attributed to a second phase of marine diagenesis (thus submersion, emersion, and submersion). The Dm (and De) deposits are "devoid of any significant interparticle marine cement" (from Meischner et al., 1995), indicating that diagenesis occurred mainly in a freshwater vadose environment after regression of sea level. Extensive neomorphism is absent from both Belmont and Rocky Bay deposits.

\subsubsection{Devonshire marine (Dm), eolian (De), and Harrington protosol $(\mathrm{Hp})$ deposits}

In contrast to the $\mathrm{Bm}$, subtidal and intertidal deposits of the Dm are coarse, crudely bedded, and poorly sorted (Fig. 4). The base often consists of a conglomerate of older limestone clasts and eroded sturdy mollusks. Most Dm coral samples have been derived from this basal conglomerate. Dm sediments generally fine upward and grade into the $\mathrm{Hp}$, whose parent material is a loosely cemented Dm marine sand.

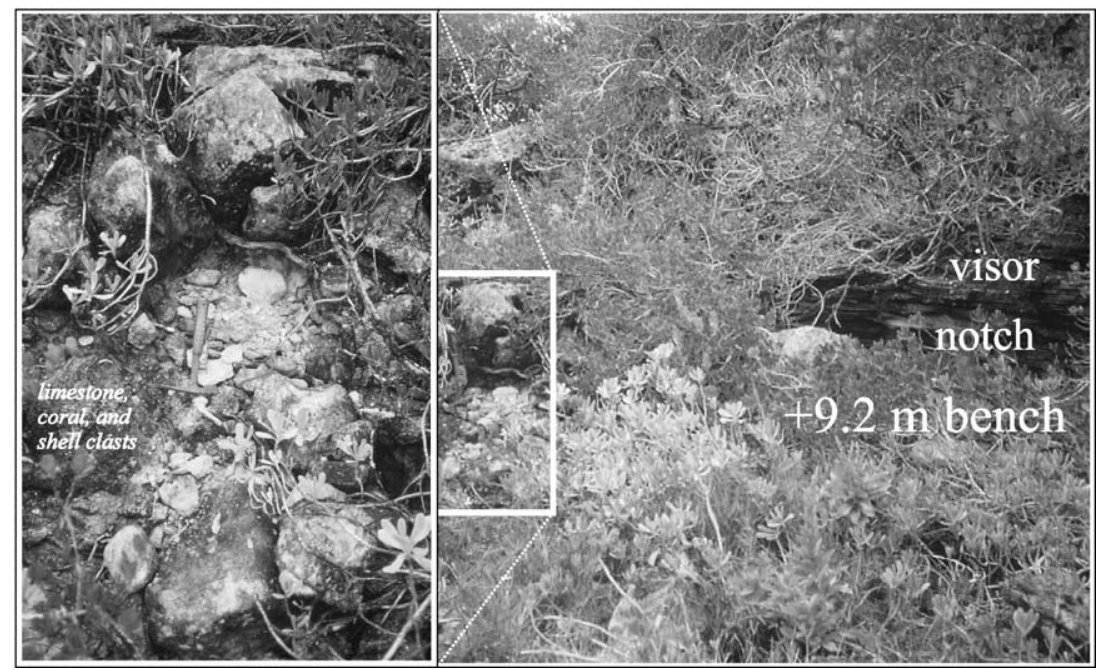

Fig. 5. Photo of rubble deposits (enlargement on left) on a $+9-\mathrm{m}$ bench and notch at Spencer's Point (Photograph in 1989 by the author). A coral cobble from these deposits yielded 130 and $98 \mathrm{ka} \mathrm{U/Th}$ ages (Land et al., 1967; Harmon et al., 1983, respectively). This deposit could not be located in 2001, and has presumably been destroyed by recent construction in the area. 
At Hungry Bay (Fig. 3, Section 8), cliff talus mantles an angular erosion surface rising from about +3.5 to at least $+6 \mathrm{~m}$. Pauses in the late Dm sea level formed notches and small rubble benches at +6 and +9 m (Land et al., 1967; Hearty and Kindler, 1995; Hearty and Neumann, 2001) (Fig. 5). A pause of sea level at $+6 \mathrm{~m}$ is marked by encrusting algae and a serpulid "reef" at Watch Hill Park (Meischner et al., 1995). In modern observations, serpulid shell accumulations are greatest in the intertidal zone. Freshwater vadose cementation and shallowing-upward deposits indicate that $\mathrm{Dm}$ is a predominantly regressive sea level deposit.

\subsubsection{Pembroke eolianite (Pe) deposits}

The Pe is a laterally extensive but thin eolianite unit capping the Hp, which always separates it from the Dm. The Pe has previously been considered a regressive eolian facies of the Rocky Bay Formation (Vacher et al., 1989). Palmetto (Sabal bermudana) frond casts among the dune bedforms are characteristic, indeed, almost diagnostic of Pe. Grains composing the eolian unit are very fine sand, unlike that of the Southampton, Rocky Bay, and Belmont dunes. Cementation of $\mathrm{Pe}$ is distinctly freshwater vadose.

Thin sets of eolian foresets with a pervasive northwest orientation (Mackenzie, 1964) dominate the Pe in all of the South Shore outcrops. As such, there is no direct indication of the position of sea level during Pe deposition. Even if near, the shoreline on the steep offshore slope of the South Shore must have been positioned significantly below present, as storm or washover deposits are not observed in Pe. Given that the Dm shows a now emergent shallowing-upward sequence (subtidal, beach, to soil), it is significant that Dm and Pe are never found in direct facies succession above sea level. They are always disconnected by a moderately developed soil-the Hp. Furthermore, the very fine sand texture of the Pe, compared to the coarse sands of Bm, Be, and Dm, suggests no correlation with these units, but instead suggests sediment from a more distant source. The widespread burial of the Sabal fronds, stems, together with entire 10-m standing trees with fronds still attached (as at Hungry Bay), indicates a well-established terrestrial environment abruptly consumed by coastal dune sand. The Pe deposits suggest a short interval of storminess, perhaps even one intense event, at a time when sea level was positioned somewhat lower than the present datum.

\subsection{Soil-like deposits and associated contacts}

At the heart of this discussion is the origin and interpretation of tan to red, soil-like deposits that interbed with or cover Bm, Dm, and Pe units along the South Shore (Fig. 6A of Section 3, UGB5 in Fig. $3)$. The surface on which these soil-like deposits rest should reflect the history of weathering and exposure of a true soil horizon (e.g., brecciated limestone in Chorizon, clay and reddening in the B-horizon, etc.). Red terra rossa deposits (Fig. 6B of Section 4, UGB6 in Fig. 3) are generally viewed as glacial-age soils (Bricker and Mackenzie, 1970), while light colored (brown, tan, or yellow) soils are generally interpreted as intra-interglacial soils or "protosols" (sensu Vacher and Hearty, 1989). Soils, red soil-like units, and exposure surfaces of several types occur in the sections along the South Shore.

The MIS 7 interpretation of the $\mathrm{Bm} / \mathrm{Be}$ implies that a glacial-age soil (reflecting $80-100 \mathrm{ka}$ of exposure or more) and a deeply weathered and karstified surface would have formed on the $\mathrm{Bm} / \mathrm{Be}$. According to Vacher et al. (1989), the Shore Hills Soil (SHs) is situated between the $\mathrm{Bm}$ and $\mathrm{Dm}$ along the South Shore. However, at the key section along the South Shore, a terra rossa soil and an associated weathering surface between $\mathrm{Bm}$ and $\mathrm{Dm}$ is not observed. At most

Fig. 6. (A) Photograph of the Grape Bay Section 3 (UGB5 in Fig. 3) showing the succession of units from Bm at the base, to Hp at the top. The red tinted "rc" unit rests conformably on the upper Bm surface, which exhibits no karst, weathering, calcrete, or other evidence of a full glacial cycle of exposure. Several transported blocks of older limestone, presumably Bm beachrock, are encased in the rc sediments. The blocks appear to have been transported concurrently with the red colluvial matrix. In cases where the Dm is thin or absent, the Hp developed on the rc, giving the appearance of a "red Harrington" soil. Abbreviations as in Fig. 3. (B) Photograph of Section 4 (UGB6 in Fig. 3) showing a typical glacialage deep red St. Georges (SG.s) soil. The reddish "rc" with reworked blocks is situated below the St. Georges soil. If a full glacial cycle separates the Belmont Formation from the Rocky Bay Formation, a soil and weathering surface similar to the St. Georges would presumably develop at their contact. Such a soil or relicts thereof have not been observed at this contact in Bermuda. 

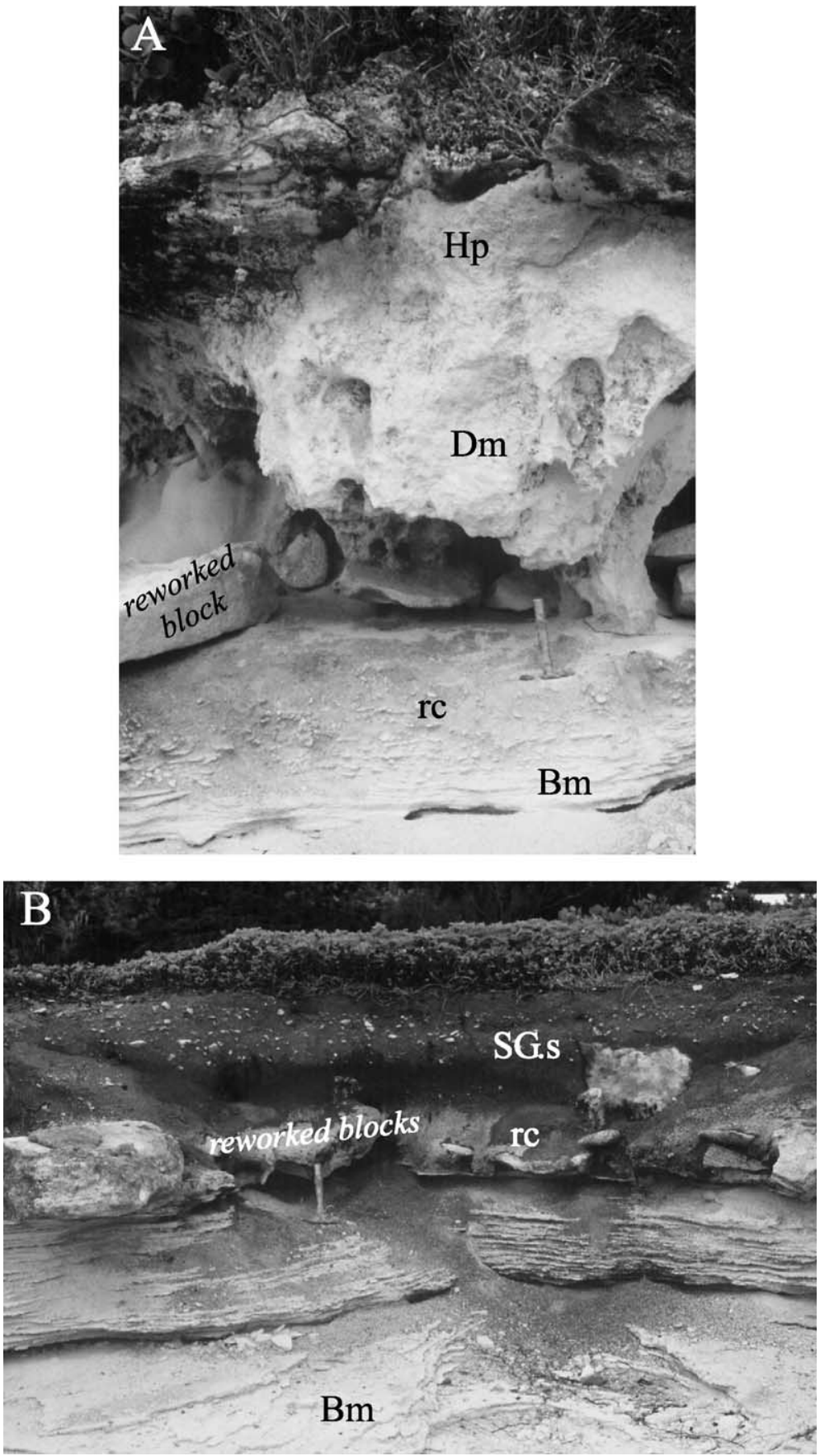

locations, the Dm rests directly upon an unweathered surface of the Bm (Fig. 3). The following soil-like units and contacts are observed along the South Shore of Bermuda.

\subsubsection{A red colluvial ("rc") unit}

At all the locations along the South Shore where it is found, the reddish soil-like deposit rests on a nearly horizontal and unweathered $\mathrm{Bm}$ or Be surface (Fig. 
6A,B). Within the rc deposit, there is neither evidence of a C-horizon (with its characteristic limestone breccia), nor a clay-enriched B-horizon typical of older soils. The unit often contains small lenses of angular limestone clasts in a matrix of relatively homogenous red silt. The clasts of older Pleistocene limestone, together with large beachrock blocks (Fig. 6B) were apparently ripped up from the $\mathrm{Bm}$, presumably by waves. The red soil-like deposit occurs in lenticular or lobate bodies in low areas of the coastline at Grape Bay and Ariel Sands (Fig. 3, Sections 2, 3, 4, and 6). These lenticular bodies persist for only $75 \mathrm{~m}$ along the coast at Grape Bay. A few tens of meters east or west, there is no trace of rc or even hints of reddening, weathering, or karstification along the $\mathrm{Bm} / \mathrm{Dm}$ contact. Although perhaps locally removed, it is unlikely that all traces of a palaeosol, including red staining, solution pits, and particularly the very resistant calcrete, could have been eroded from all locations on Bermuda.

\subsubsection{The Bm/Dm contact}

In the Bahamas, limestone surfaces have been classified according to comparative "stages" of weathering and exposure of surfaces (Hearty and Kindler, 1997; Hearty, 1998). A full glacial weathering surface should reveal red, silty to clayey soils, a 1-3-cm-thick calcrete horizon, and karstic pits up to a few decimeters deep. At the $\mathrm{Bm} / \mathrm{Dm}$ contact, the surface is clean, unstained, relatively weakly cemented, and often nearly conformable with the overlying unit. At no known location is the $\mathrm{Bm} / \mathrm{Dm}$ contact stained with translocated red clays, indurated with cementation or calcrete, or dissolved by meteoric processes into karst pits or pipes. The growth of vegetation and the powerful prying action of roots over a full glacial cycle would certainly result in the "brecciation." of the underlying bedrock; these characteristics, including solution pipes, calcrete, and brecciation in the C-horizon, are common in other palaeosols of various ages around Bermuda.

Casts of Sabal stumps are preserved in marine sands in the Bm along Rocky Bay and Grape Bay (in UGB4, Fig. 3). Colonization by palmettos must have occurred on unconsolidated beach and subtidal sands, following the $\mathrm{Bm}$ regression from the $+2.5-\mathrm{m}$ sea level. Subsequent induration of the sands must have occurred with sufficient speed to cast trunks and rootlets in replicate form. Furthermore, preservation of molds in such detail implies that no significant erosion or dissolution had occurred in or around the pits between $\mathrm{Bm}$ and $\mathrm{Dm}$. Some Sabal casts are filled with the red colluvium, while others are filled with Dm sands.

Glacial-age weathering characteristics should be conspicuous and widely preserved based on similar examples from the Bahamas (Hearty and Kindler, 1997; Hearty, 1998). For the middle Pleistocene interglaciations, these would include a deeply dissolved karst surface mantled by a massive, casehardened calcrete between 5 and $20 \mathrm{~cm}$ thick. This exposure surface is locally overlain by a red to deepred clayey soil, preserved mainly in solution pits and depressions. Yet, even with the extensive $\mathrm{Bm} / \mathrm{Dm}$ surface on Bermuda, such weathering features or remnants of them are not found at this contact.

\subsubsection{The Be/Pe contact}

A trench was excavated during the 19th Century to access Devonshire Bay Fort about $50 \mathrm{~m}$ inland from the type section of the Rocky Bay Formation (Fig. 3). In this shoreward trench, the Dm and Hp feather out, leaving the Be and Pe separated only by a thin red silt containing land snails. The delicate Poecilozonites snail shells are preserved in a pristine condition, remaining uncalcified and retaining their primary colors. As in the coastal sections, the upper Be surface is clean, fresh, and thinly stained with red clay, but reveals no calcrete, solution pits, or karstification indicative of 80-100 ka of exposure. The climate of Bermuda could not have been significantly different from that in the Bahamas, where clayey red soils, deeply weathered surfaces, and calcrete are characteristic of middle and late Pleistocene palaeosols of both island groups.

\subsubsection{The Harrington protosol ( $\mathrm{Hp})$}

The widely recognized "Harrington" protosol is a landward weathered facies of the underlying Dm marine unit (Fig. 6A). Coarse and poorly sorted bioclastic marine sand and shells, characteristic of the parent material, are abundant in the lower part of Hp. Higher in the unit rhizomorphs and Poecilozonites land snails are more plentiful. The marine shell Cittarium pica, probably transported inland by the hermit crab Ceonobita clypeatus, is also abundant. This assemblage of physical and biological features reflects the 
sustained activity of organisms in a predominantly terrestrial environment. At an outcrop near the seaside swimming pool at Ariel Sands (Fig. 3, Section 6), on Bm bedrock, a thin Dm and Hp are stained a deep red color (a.k.a. the "red Harrington").

At Grape Bay, the top $\sim 20 \mathrm{~cm}$ of $\mathrm{Hp}$ is dense, silty, reddish-yellow ( 7.5 YR 7/6, Munsell, 1994), and capped by a $1-2-\mathrm{cm}$ calcrete. At Hungry and Rocky Bays, a few tens of meters landward of the coastline, the Hp grades directly into a thin, deep-red silty unit, sandwiched between $\mathrm{Bm}$ and Pe eolianites. Despite its color, this landward "red Harrington" fulfills none of the previously mentioned characteristics of a glacial-age paleosol.

\subsubsection{The $\mathrm{Hp} / \mathrm{Pe}$ contact}

The 1-2-cm-thick calcrete at the top of Hp reflects sustained calcite precipitation at an inter-unit contact. There are some local patches of soil above the calcrete, particularly where the $\mathrm{Pe}$ is thin or broken by roots, but generally, the Pe lies directly on the calcrete on $\mathrm{Hp}$. The silt, color, and calcrete indicate prolonged exposure of the Hp surface.

\subsubsection{The St. Georges soil (SGs)}

The SGs mantles the low-coastal sections in the study area, particularly the east end of Grape Bay (Fig. 6B). The deep-red loamy silt developed during multiple climate and sea level cycles since MIS 5 e. When developed on the Pe, it forms an undulating weathered surface up to $0.5-\mathrm{m}$ deep. This soil continues to develop today in areas where it is not buried by coastal sands.

\subsection{Geochronology}

\subsubsection{Uranium-thorium (U-series) alpha spectrom- etry dating}

Harmon et al. (1978, 1983) collected and dated coral cobbles in detached bedrock blocks, basal conglomerates, "cliff plaster" (marine calcarenite cemented to older bedrock cliffs), and notch fillings. Bermuda fossil corals are rarely preserved in growth position. Under such reworking conditions, the true age of the deposits can only be approximated by the youngest $\mathrm{U} / \mathrm{Th}$ age derived from the deposits. Yet reworking of corals exclusively from older interglaciations remains a possibility, as documented below.
Harmon's study reported U/Th ages, but unlike outcrops from the Bahamas (e.g., Chen et al., 1991), none of the corals have a secure enough provenance to document paleo-sea levels. Corals ages of $>300$ and $222^{+30 /-21} \mathrm{ka}$, and $228^{+24 /-18}$ and $200^{+20 /-16} \mathrm{ka}$ were derived from a $+1-\mathrm{m}$ conglomerate, and $\mathrm{a}+3-$ $\mathrm{m}$ notch, respectively, in the Walsingham Formation at Stokes Point. A Porites age of $208^{+20 /-16} \mathrm{ka}$ age was determined from a "sandy infilling of a $+1-\mathrm{m}$ notch in Belmont eolianite" (Harmon et al., 1983). Their sample 780525-2 on Siderastrea from an in situ vermetid reef "bioler [sic]" block at $+1 \mathrm{~m}$ on Belmont beachrock" from Boaz Island (Table III in Harmon et al., 1983) in the far northwest of Bermuda returned an average age of $204 \mathrm{ka}$. Although the corals are described as in situ, their provenance appears to be from a dislodged (?) "block" resting above sea level. A $262^{+35 /-27}$-ka age from Oculina in Bm at East Grape Bay suggests reworking of coral clasts from MIS 8 or 9 deposits. The mid-glacial age (262 ka) of this sample otherwise hints of chemical problems.

Harmon et al.'s $(1978,1983)$ U-series coral ages from sandy infillings of $+3-\mathrm{m}$ notches in middle Pleistocene limestone at four localities are $228^{+24 /-18}$ and $200^{+20 /-16} \mathrm{ka}$ (Stokes Point), $118 \pm 11 \mathrm{ka}$ (Winsor House), $124 \pm 12 \mathrm{ka}$ (Convict Bay), and $127 \pm 6 \mathrm{ka}$ (Watch Hill Park). A mean paleo-sea level of $+2.5 \pm 0.3 \mathrm{~m}$ can be traced laterally across the study area (Fig. 3) to Watch Hill Park where a " $+3-\mathrm{m}$ notch" is observed (Harmon et al., 1983). These sections in Fig. 3 demonstrate the transition from sediment-dominated to rocky coastline. The $+2.5-\mathrm{m}$ sea level in the $\mathrm{Bm}$ is expressed along the sedimentary coastlines as the transition from subtidal to intertidal sedimentary structures. On rocky coastlines or interior sounds where older middle or early Pleistocene outcrops dominate, notches at around +3 and $+6 \mathrm{~m}$ are commonly observed. If the youngest U/Th coral ages of deposits in three of four $+3-\mathrm{m}$ notches on Bermuda are correct, then it is reasonable to conclude that the notch at Watch Hill Park was filled as recently as $127 \pm 6$ ka ago. As such, the " $+3-\mathrm{m}$ " Bm shoreline is thus directly tied to early MIS $5 \mathrm{e}$.

\subsubsection{Aminostratigraphy of South Shore deposits}

Hearty et al. (1992) analyzed the whole-rock bioclastic limestone, marine shells (Glycymeris, Bra- 
Table 2

$A / I$ data from several taxa presented in field-based stratigraphic succession from top to base

\begin{tabular}{|c|c|c|c|c|}
\hline Stratigraphic unit & Glycymeris sp. & Brachiodontes exustus & Poecilozonites sp. & Whole-rock \\
\hline $\begin{array}{l}\text { Former Pembroke Mb } \\
\text { (New Hungry Bay Fm) } \\
\text { eolianite }(\mathrm{Pe})\end{array}$ & & $0.62 \pm 0.02(2) \mathrm{SH}$ & & $\begin{array}{l}0.27 \pm 0.03(12) R B \\
0.27 \pm \mathbf{0 . 0 1 ( 1 ) H B} \\
\mathbf{0 . 3 5} \pm \mathbf{0 . 0 1 ( 1 ) R B T}\end{array}$ \\
\hline $\begin{array}{l}\text { Harrington } \mathrm{Mb} \\
\text { protosol }(\mathrm{Hp})\end{array}$ & & & $\begin{array}{l}0.49 \pm 0.03(8) \mathrm{MB} \\
0.45 \pm 0.01(2) \mathrm{WH} \\
0.47 \pm 0.01(2) \mathrm{CB} \\
0.50(1) \mathrm{GB} \\
0.50 \pm 0.01(2) \mathrm{WB} \\
0.52 \pm 0.01(3) \mathrm{RB} \\
0.50 \pm 0.01(4) \mathrm{BWP} \\
0.46 \pm 0.02(2) \mathrm{SH}\end{array}$ & $0.42 \pm 0.00(2) \mathrm{RBT}^{\mathrm{a}}$ \\
\hline $\begin{array}{l}\text { Devonshire } \mathrm{Mb} \text {, } \\
\text { marine }(\mathrm{Dm})\end{array}$ & $\begin{array}{l}0.44 \mathrm{~GB}, \\
0.57 \pm 0.07(4) \mathrm{GB}, \\
0.55 \mathrm{SH} \\
0.58 \pm 0.03(5) \mathrm{WB}\end{array}$ & $\begin{array}{l}0.71 \pm 0.05(2) \mathrm{RB} \\
0.66 \pm 0.01(2) \mathrm{RBW} \\
0.71 \pm 0.01(2) \mathrm{BH}\end{array}$ & & $0.30 \pm 0.02(18) \mathrm{RB}$ \\
\hline $\begin{array}{l}\text { Devonshire } \mathrm{Mb} \text {, } \\
\text { eolianite }(\mathrm{De}) \\
\text { and protosol }\end{array}$ & & & $\begin{array}{l}0.57 \pm 0.02(6) \mathrm{BWP} \\
0.57 \pm 0.03(3) \mathrm{MB} \\
\mathbf{0 . 5 7} \pm \mathbf{0 . 0 1 ( 9 )} \mathbf{A D}^{\mathrm{b}}\end{array}$ & \\
\hline $\begin{array}{l}\text { Former Belmont } \\
\text { (New Grape Bay Mb) } \\
\text { eolian (Be) }\end{array}$ & & & & $\begin{array}{l}0.38 \pm 0.01(2) \mathrm{RB} \\
0.41 \pm 0.04(2) \mathrm{RBW} \\
0.38 \pm 0.01(2) \mathrm{SH} \\
\mathbf{0 . 4 1} \pm \mathbf{0 . 0 1 ( 1 ) H B}\end{array}$ \\
\hline $\begin{array}{l}\text { Watch Hill Park } \\
\qquad(+3-\mathrm{m} \text { notch, } 127 \mathrm{ka})\end{array}$ & $0.70 \pm 0.03(7) \mathrm{WHP}^{\mathrm{c}}$ & & & $\begin{array}{l}0.41 \pm 0.01(2) \mathrm{WHP}^{\mathrm{c}}, \\
\mathbf{0 . 3 7} \pm \mathbf{0 . 0 1 ( 1 ) W H W}\end{array}$ \\
\hline $\begin{array}{l}\text { Former Belmont } \\
(\text { New Grape Bay } \mathrm{Mb}), \\
\text { marine }(\mathrm{Bm})\end{array}$ & & $\begin{array}{l}0.75 \mathrm{BWP} \\
\mathbf{0 . 7 5} \pm \mathbf{0 . 0 2 ( 2 ) G B} \\
\mathbf{0 . 7 6} \pm \mathbf{0 . 0 1 ( 2 ) H B}\end{array}$ & $\begin{array}{l}0.61 \pm 0.05(10) \mathrm{SH} \\
\mathbf{0 . 6 2} \pm \mathbf{0 . 0 2 ( 3 )} \mathbf{A D}^{\mathrm{b}}\end{array}$ & $0.41 \pm 0.01(1) \mathrm{HB}$ \\
\hline
\end{tabular}

The notation is $0.45 \pm 0.02(5)$ where 0.45 is the mean, 0.02 is one sigma $(\sigma)$, and 5 is number of shells analyzed.

Site abbreviations: RBW= Rocky Bay W.; HB=Hungry Bay; $\mathrm{MB}=$ Mullet Bay; RB=Rocky Bay; $\mathrm{SH}=\mathrm{Saucos} H \mathrm{Hill}$; $\mathrm{BH}=\mathrm{Barkers}$ Hill; $\mathrm{BWP}=$ Blackwatch Pass; $\mathrm{GB}=$ Grape Bay; $\mathrm{WHP}=$ Watch Hill Park; WB = Whalebone Bay; WH=Winsor House; MB=Mullet Bay; $\mathrm{RBT}=$ Rocky Bay Type $\mathrm{CB}=$ Convict Bay; $\mathrm{AD}=$ Admiral's Cave.

${ }^{\text {a }} A / I$ ratio reflects probable heating of soil sample.

b Admiral's Cave samples with Belmont ratios are constrained to an age of $<126.3 \pm 0.9 \mathrm{ka}$ (Hearty et al., unpublished).

${ }^{c}$ Deposits from the $+3-\mathrm{m}$ notch at Watch Hill Park are equated with a U/Th age of $127 \pm 6$ ka (Harmon et al., 1983).

chiodontes, Lucina), and Poecilozonites land snails from the complete Bermuda stratigraphy. These data distinguished $\mathrm{Bm} / \mathrm{Be}, \mathrm{Dm} / \mathrm{De}, \mathrm{Hp}$, and Pe with $A / I$ ratios comprising aminozones (Fig. 7, Table 2). Since 1992, many more samples have been analyzed from Bermuda (bold in Table 2). D-alloisoleucine/Lisoleucine (or $A / I$ ) ratios confirm lithostratigraphic order in $97 \%$ of the over 300 sample cases. In this study, there is no attempt to alter the concordance between Vacher et al.'s (1989) stratigraphic order and $A / I$ ratios; only to demonstrate that those previously interpreted as Belmont $=$ MIS 7 (Hearty et al., 1992) are more appropriately correlated with early MIS 5e.

\subsubsection{Epimerization kinetics}

Demonstrated both theoretically and empirically through controlled pyrolysis experiments, the rate of epimerization is known to increase exponentially in response to increasing temperature (Hare and Mitterer, 1967). Unfortunately, this factor was not fully considered in Hearty et al. (1992). Although difficult to quantify due to the lack of independent ages, it was apparent in natural stratigraphic settings that epimerization rates were profoundly accelerated during warmer or prolonged interglacial cycles (Hearty, 1987; Hearty and Aharon, 1988). Given equivalent burial and diagenetic conditions, as with Bermudatype examples, it is recognized that a sample depos- 
ited at the beginning of MIS 5e (ca. $130 \mathrm{ka})$ would experience significantly more interglacial warmth than one deposited at the end of MIS 5e (120 ka). This would account for an estimated epimerization difference of $0.10-0.15 \mathrm{~A} / \mathrm{I}$ between the beginning and end of MIS 5e. Somewhat cooler conditions would prevail after MIS 5e (Cortijo et al., 1999), and much cooler conditions would prevail during glacial MIS 4-2 (Sachs and Lehman, 1999), until the early part of the Holocene.

Hearty and Aharon (1988) documented rapid epimerization during the Holocene and MIS 5e in Tridacna when calibrated with ${ }^{14} \mathrm{C}$ and $\mathrm{U} / \mathrm{Th}$ ages. This "interglacial effect", combined with an early rapid phase of epimerization (Hearty and Dai Pra, 1992), was also demonstrated with Helix (land snails) and Glycymeris (marine pelycepod) from the Mediterranean basin (Hearty, 1986, 1987). A/I differences of similar magnitude as those proposed in Bermuda are demonstrated in Holocene examples from the Bahamas (Hearty and Kaufman, 2000) that have endured only 5-6 ka of epimerization. Miller et al. (1999) correlated A/I ratios from fossil eggshells of Genyornis and Dromaius with over 100 radiometric and optically stimulated luminescence dates, showing the profoundly nonlinear rate changes of epimerization during the Holocene and interglacial intervals.

Given Bermuda's $\sim 20{ }^{\circ} \mathrm{C}$ current mean annual temperature (MAT), the effect of an increase of $2{ }^{\circ} \mathrm{C}$ in MAT during $\sim 10 \mathrm{ka}$ of interglacial climate, would result in an increased $A / I$ ratio of approximately $\sim 0.13$ (i.e., $0.50-0.63$ ) in Glycymeris (estimated from the global $A / I$ epimerization curve of Hearty and Miller, 1987). Whereas a similar cooler shift in temperature during a glacial cycle in Bermuda (generally 5 to $10{ }^{\circ} \mathrm{C}$ cooler for perhaps $50-70 \mathrm{ka}$, Cortijo et al., 1999; Sachs and Lehman, 1999) would have a negligible effect on $A / I$ of only $\sim 0.03$. Thus, the sum of these climatically driven components suggests that a major part of the $A / I$ epimerization since $132 \mathrm{ka}$ occurred during MIS 5 and MIS 1 interglaciations.

The kinetic pathways of four taxa are plotted in black lines in Fig. 7. These trends reflect the $\mathrm{Bm}=$ early MIS 5e interpretation of the South Shore

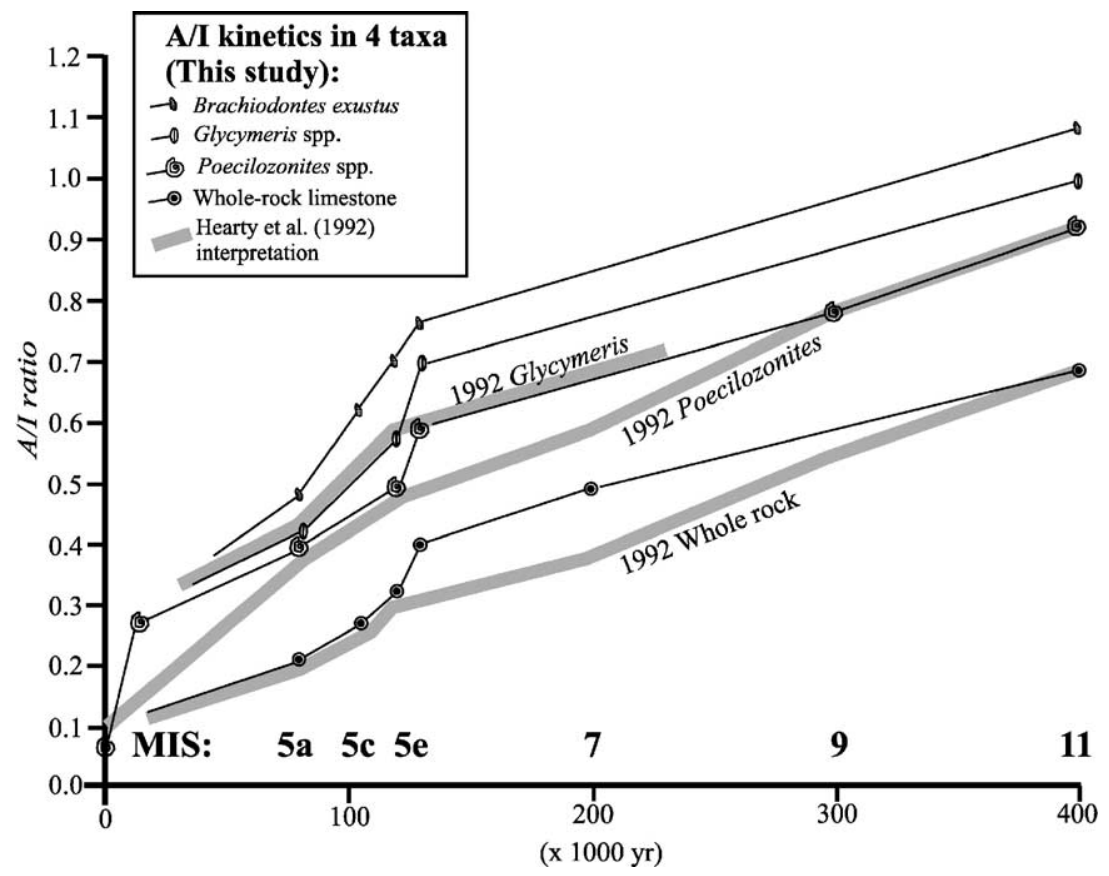

Fig. 7. Plot of average $A / I$ ratios of four taxa versus chronometric ages of the source deposits (Harmon et al., 1978, 1983; Ludwig et al., 1996; Hearty et al., 1999). The graphs, keyed to an early MIS 5e Belmont, show the profound changes in epimerization rate under the influence of interglacial warmth. Half tone lines indicate the previous interpretation of Hearty et al. (1992). 
deposits. Independent U-series calibrations at $\sim 82$ ka (Ludwig et al., 1996), $100 \mathrm{ka}$ for the Pe (Harmon et al., 1978, 1983; Vollbrecht, 1990), and estimates of $\sim 125 \pm 6 \mathrm{ka}$ for the $\mathrm{Dm}$ and the Belmont strengthen this interpretation. Fig. 7 shows the direct influence of warmer temperatures during MIS 5 and 1 on the epimerization rate. The previous $\mathrm{Bm}=$ MIS 7 interpretation having only one mean value at ca. $125 \mathrm{ka}$ (Hearty et al., 1992) (half tone in Fig. 7) does not consider the temperature effect on epimerization rate for $10-15 \mathrm{ka}$ during MIS 5e.

\subsubsection{Evidence from amino acid data}

AAR data from several Bermuda localities support a younger MIS 5e interpretation of the Belmont Formation.

(1) Whole-rock A/I ratios-Typical $\mathrm{Bm}$ and $\mathrm{Be}$ deposits at Rocky Bay, Rocky Bay West, Saucos Hill, Hungry Bay, and Grape Bay sites yielded a grand whole-rock mean $A / I$ of $0.40 \pm 0.02(n=13)$. This mean is correlated with one of $0.41 \pm 0.01 \quad(n=2)$ from carbonate sand within the $+3-\mathrm{m}$ notch at Watch Hill Park. A coral clast enclosed within the sand produced an age of $127 \pm 6 \mathrm{ka}$. Although it is possible that the whole-rock sediment may have formed on the southern shelf before the growth of the corals, it is also possible that their formation is penecontemporaneous, and that they were transported to the notch at about the same time during early MIS 5e.

The type Rocky Bay and several other sites returned Dm whole-rock $A / I$ ratios between 0.30 and 0.35 , while the Pe is firmly equated with a mean of $0.27 \pm 0.03(n=13)$. On the basis of our climatesensitive kinetic model, and the implied correlation between the $127 \pm 6 \mathrm{ka}$ coral age and the South Shore mean of 0.40 , the $\mathrm{Bm}$ and $\mathrm{Dm}$ are interpreted to correlate with early and late MIS 5e.

Meischner et al. (1995) reported a + 7.5-m "Belmont" sea level from a site located $80 \mathrm{~m}$ west of the +3-m notch at Watch Hill Park. An A/I ratio of 0.37 ratio from these deposits indeed correlates them with $\mathrm{Bm} / \mathrm{Be}$ (Table 2). However, careful investigation of their site revealed beach fenestrae as low as $+3.5 \mathrm{~m}$, leaving their interpretation of a $+7.5-\mathrm{m}$ sea level without critical sedimentological support. This study correlates their $\mathrm{Bm} / \mathrm{Be}$ deposits and a $+3-\mathrm{m}$ sea level with early MIS $5 \mathrm{e}$.
(2) Glycymeris A/I ratios-Mean Glycymeris A/I ratios from the $\mathrm{Bm}+3-\mathrm{m}$ notch at Watch Hill Park were likewise previously correlated with MIS 7 (Hearty et al., 1992). However, the $0.70 \pm 0.03(n=7)$ mean $A / I$ ratio for Glycymeris was obtained from the same notch-filling deposit yielding the $127 \pm 6 \mathrm{ka}$ coral age (Harmon et al., 1983). The stratigraphically younger $\mathrm{Dm}$ produced a Glycymeris mean of $0.58 \pm 0.04(n=10)$. In 1992, this range of ratios was not considered to "fit" within MIS 5e. We now recognize the importance of prolonged interglacial warmth on epimerization rate, and propose a correlation of both averages $(0.70$ and 0.58$)$ with early and late MIS 5e.

(3) B. exustus A/I ratios-At Blackwatch Pass and Barker's Hill on the North Shore (accepted to be MIS 5 e deposits), B. exustus ratios of $0.75(n=1)$ and $0.71 \pm 0.01(n=2)$ were returned from lower and higher units (Fig. 8), respectively, while the $\mathrm{Bm}$ at Grape and Hungry Bays produced a collective $B$. exustus mean $A / I$ ratio of $0.76 \pm 0.02(n=4)$. Average South Shore Dm and Pe Brachiodontes ratios are $0.70 \pm 0.03(n=5)$ and $0.62 \pm 0.02(n=2)$, respectively. On the basis of the similarity of Brachiodontes ratios from the North and South Shore deposits, I infer a MIS 5e correlation of these units across Bermuda (Fig. 8).

(4) Poecilozonites A/I ratios-A/I ratios from Poecilozonites in upper and lower protosols in Blackwatch Pass produced $A / I$ ratios of $0.50 \pm 0.01(n=4)$ and $0.57 \pm 0.02(n=6)$, respectively (Fig. 8). There is no terra rossa palaeosol exposed in Blackwatch Pass, and the general view is that the entire section is last interglacial age (Vacher et al., 1989, 1995; Hearty and Kindler, 1995). Early on, Hearty in Vacher et al. (1995) pointed out that the lower Blackwatch Pass and Saucos Hill A/Is of 0.57 to 0.61 from Poecilozonites were more appropriately correlated with early MIS 5e, than with older deposits.

The combined Poecilozonites A/I ratios from the South Shore Harrington protosol and pre-Rocky Bay deposits average $0.50 \pm 0.02(n=6)$ and $0.59 \pm 0.03$ $(n=19)$, respectively. At Saucos Hill on the South Shore, P. bermudensis and P. cupula A/I ratios from a mapped "pre-Devonshire" Be protosol yielded a mean of $0.61 \pm 0.05(n=10)$. This thin protosol at Saucos Hill (Fig. 3, Section 10) lies beneath a reddened deposit now recognized as the "rc". Considering all the data, it is now evident that the $0.61 \pm 0.05$ 
North Shore

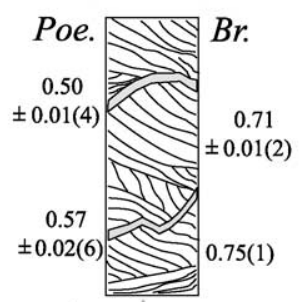

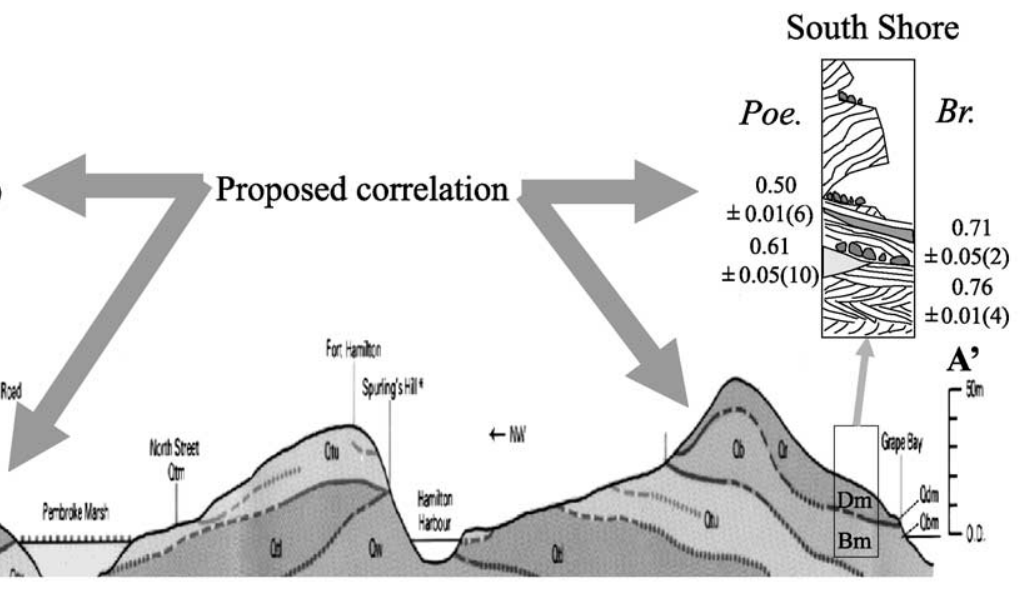

GEOLOGICAL MAP OF BERMUDA

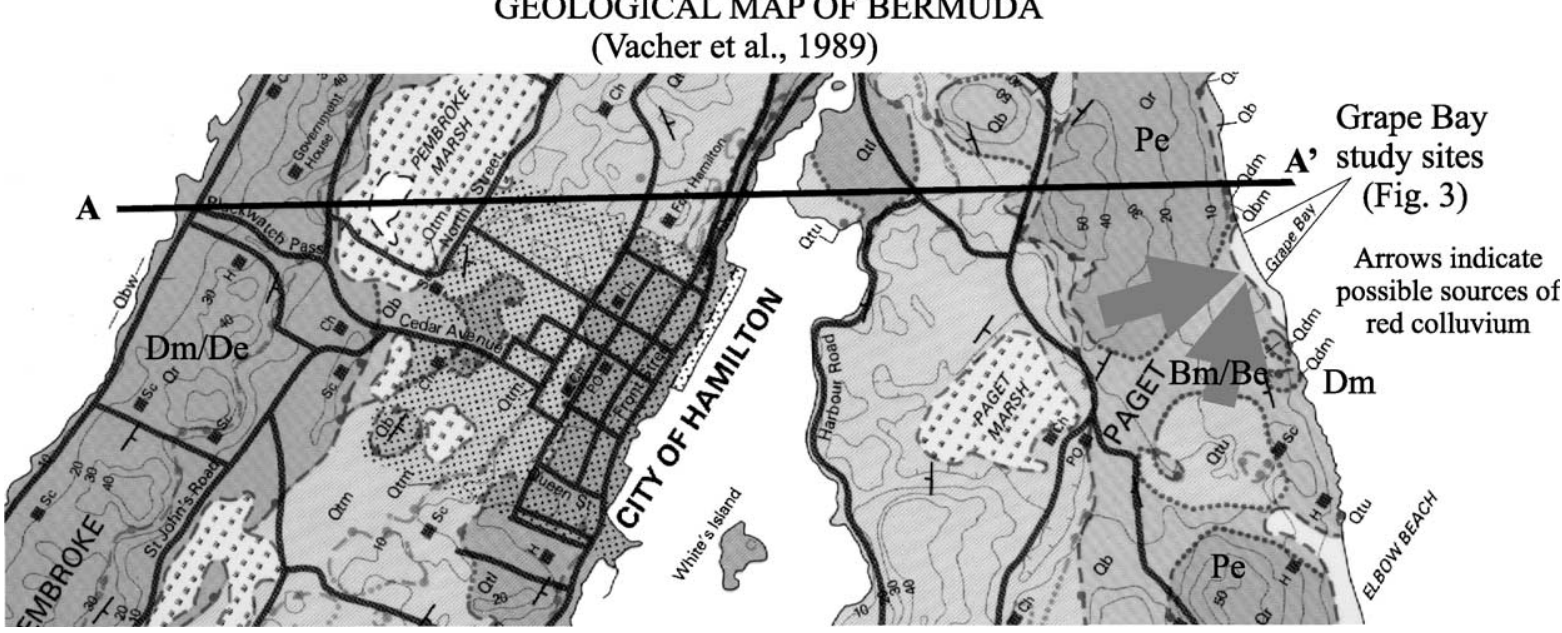

Fig. 8. A correlation of northern and southern shore sections (A- $\mathrm{A}^{\prime}$ in Fig. 1) based primarily on equivalent mean Poecilozonites (Poe.) and B. exustus (Br.) A/I ratios. This correlation between Blackwatch Pass and Grape Bay supports an early MIS 5e age of the Belmont Formation along the South Shore of Bermuda.

$(n=10)$ from Saucos Hill and the overall South Shore mean of $0.59 \pm 0.03(n=19)$ are correlated with early MIS 5e. A new constraining TIMS age on a basal flowstone of $126.3 \pm 0.9 \mathrm{ka}$ from talus deposits in Admiral's Cave (Fig. 1; Table 2) confirms that $P$. bermudensis A/I ratios between $0.57 \pm 0.02 \quad(n=6)$ and $0.62 \pm 0.02(n=3)$ belong to the early part of MIS 5e (Hearty and Edwards, unpublished).

\section{Discussion}

Bermuda's preeminent status as a global sea-level "tide gauge" is compromised and paradoxical when global views of MIS 5e and 7 highstands are considered. According to previous geological mapping, emergent MIS 7 marine deposits along the South Shore are widespread and extensive, while MIS 5e deposits are scarce, consisting of a few isolated patches of regressive Dm sands. Further, if, Pe is not considered an eolian facies of Dm, as proposed here, the relative volume of MIS 5e deposits is miniscule.

The $\mathrm{Bm}=$ MIS 7 interpretation was based on inadequate field evidence, particularly on the occurrence of red, soil-like deposits in lobate bodies between the Bm and $\mathrm{Dm}$ at a few locations. The relative induration of the $\mathrm{Bm}$, and a preliminary interpretation of $A / I$ ratios were also considered as support for the $\mathrm{Bm}=$ MIS 7 . 
The findings from this study document that the $\mathrm{Bm}$ and Be surface is typically unweathered, unindurated, and lacks solution pits, red staining, and calcrete formation. In a majority of exposures on Bermuda, the absence of red pedogenic deposits, or even remnants of them in pits or depressions, argues that a soil did not develop on this surface. It is highly improbable that all soil-related features have been completely and totally removed by erosion, when parallel glacial-age soils are abundant throughout the stratigraphy of the island.

It is proposed in this study that red colluvium (rc) at Grape Bay, Ariel Sands, and Saucos Hill was deposited in back-beach depressions or swales behind the 5e beach barrier (like modern examples at Hungry Bay and Spittal Pond, Fig. 3), and locally washed to the sea during heavy seas or floods. Large ripup blocks of older limestone within the rc matrix were clearly deposited by water under high energy conditions. The erosion of middle Pleistocene soils from the neighboring hillsides may have been initiated by deforestation by fire or climate change, backflow from large waves (Hearty, 1997), torrential rainfall, or some combination of these mechanisms.

In addition to the physical evidence for a younger Belmont Formation, amino acid ratios and U-series data confirm the correlation of the $+3-\mathrm{m}$ shoreline with early MIS 5e. A simplistic AAR kinetic model (Hearty et al., 1992) found agreement with the stratigraphic succession of Vacher et al. (1989). Since then, a greater understanding of the kinetic effects of interglacial warmth on epimerization rate was realized (e.g., Miller et al., 1999). It is now apparent that the epimerization reaction responded sensitively to warmer and cooler climate cycles of Bermuda, particularly that between early and late MIS 5e.

This study has also determined that the upper Hp, as a weathered facies of Dm, was exposed to meteoric weathering long after the regression from the Dm highstand. The ferruginous coloration, accumulation of silt in the B-horizon in its uppermost $20 \mathrm{~cm}$, and capping 1-2-cm calcrete indicates prolonged exposure of the Harrington surface before the deposition of the so-called "Pembroke dune".

\subsection{Implications for sea-level history in Bermuda}

A thorough, field-based study and reexamination of South Shore Bermuda over the past several years has resulted in a significant revision of its sea level history (Fig. 9). Beach facies representing the early Belmont reveal a minor stillstand at $+1 \mathrm{~m}$ (perhaps accounting for Harmon's + 1-m notch deposits and Meischner et al.'s, 1995 lower Bm unit), followed by prolonged stability of palaeo-sea level at $+2.5 \mathrm{~m}$. A subtidal-to-intertidal facies transition at $+2.5 \mathrm{~m}$ is observed along sedimentary coastlines of the South Shore, and by a +2 - to $+3-\mathrm{m}$ notch along erosional, rocky coastlines around the island. Sediment filling the $+3-\mathrm{m}$ notch at Watch Hill Park (Fig. 3, Section 11) contained coral cobbles that returned a $127 \pm 6$ ka age (Harmon et al., 1983), providing independent calibration for $A / I$ ratios on penecontemporaneous sediment and shells from the same notch. Corals from two additional $+3-\mathrm{m}$ notches at Windsor House and Convict Bay yield U/Th ages of 118 and $124 \mathrm{ka}$ (Harmon et al., 1983), respectively. Notches and shore deposits at +1 and +3 m may correspond to initial and prolonged $\mathrm{Bm}$ highstands (Meischner et al., 1995). These two levels may further equate with clusterings of coral cobble ages of around 200 to $>300 \mathrm{ka}$ (in the +1 -m notch), and 118 to $200 \mathrm{ka}$ (in the +3 -m notch). Whereas the lower level may reflect redeposition of pre-MIS 5e cobbles during the initial interglacial transgression to $+1 \mathrm{~m}$ (and before development of a MIS 5e reef), the subsequent +3 -m level may indicate reworking of mixed MIS 5e and older cobbles after several thousand of years development of the reef.

Growth of S. bermudana in beach and subtidal Bm deposits marks the mid-MIS 5e regression from the $+2.5-\mathrm{m}$ highstand. In order to form the casts, the palmettos must have grown in soft marine sands as sea level fell. Induration of the sands must have been rapid in order to preserve the detail of trunk and roots in cemented marine sand, while erosion must have been minimal to preserve these details.

As the Dm transgression ensued, the rising seas periodically washed higher, weathered slopes, mantled with deep red soils of middle Pleistocene. I propose that both the red colluvium and beachrock blocks were dislocated and deposited as lenticular bodies in depressions behind the Bm shoreline (Fig. 8). In a parallel scenario in Oahu, HI, thick lenses of land-derived basalt conglomerate separate two MIS 5e phases of coral growth (Muhs and Szabo, 1994; Hearty et al., 2000).

The Dm conglomerate has yielded numerous coral ages ranging from 134 to $118 \mathrm{ka}$ (Harmon et al., 1978, 


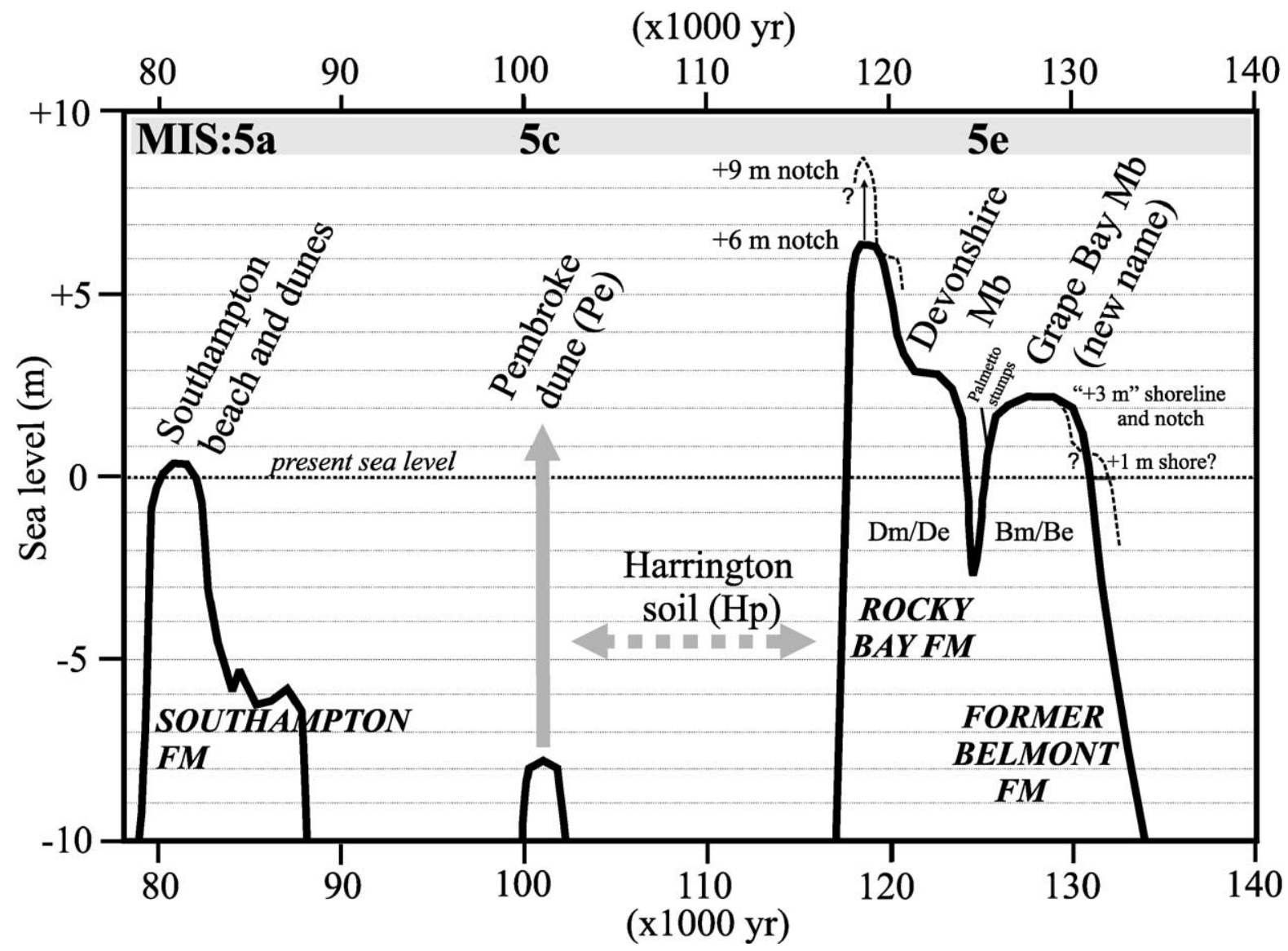

Fig. 9. Revised sea-level curve for Bermuda during MIS 5 from 140 to $80 \mathrm{ka}$.

1983). A distinct bench is associated with the Dm is present at $+6 \mathrm{~m}$ at Watch Hill Park (Meischner et al., 1995). The maximum reach of the Dm transgression may be recorded in the Spencer's Point conglomeratefilled notch and bench at $+9.2 \mathrm{~m}$ (Land et al., 1967; Hearty et al., 1989, unpublished survey). A coral cobble collected from the $+9.2-\mathrm{m}$ deposit (Fig. 5) produced an initial U/Th age of $130 \pm 15 \mathrm{ka}$ (Land et al., 1967). Subsequent reanalyses (Harmon et al., 1983 ) yielded an average of $97 \pm 9 \mathrm{ka}$. The average of these analyses may indeed reflect a highstand maximum between 115 and $120 \mathrm{ka}$ (Neumann and Hearty, 1996; Hearty and Neumann, 2001). Extensive De eolianite occurs on the north shore at Blackwatch Pass where the broad and shallow shelf, and perhaps weather conditions were more amenable to eolian transport. As sea level regressed from the Dm high- stand, fresh marine sands were exposed to terrestrial colonization by vegetation, land snails, and Cittarium shells transported by hermit crabs.

An early $\mathrm{Bm}=$ MIS 5e falls directly in line with multiple phases of deposition in Blackwatch Pass (Fig. 8), as initially postulated by Hearty and Kindler (1995). The lowest beach-complex in the road cutting equates with the $\mathrm{Bm} / \mathrm{Be}$ on the South Shore, while the middle unit lies within the $\mathrm{Dm} / \mathrm{De}$ complex (the north lagoon being better suited for the formation of De eolianites). The scour surface, mantled with planar beach-like beds up to $+18 \mathrm{~m}$ along the north shore, may have resulted from high sea level and wave run up late in MIS 5e (Hearty, 1997). The large wave hypothesis (Hearty et al., 1998), which could account for the timing and mechanism of emplacement of rc, was questioned by Kindler and Strasser (2000), confronted 
by Hearty et al. (2002), and further debated by Kindler and Strasser (2002). As suggested by Land et al. (1967), the Spencer's Point outcrop and bench at +9 $\mathrm{m}$ in Town Hill rocks may record a brief, maximum highstand at the end of the interglaciation. The complexity observed from MIS 5e deposits in Bermuda is not unique to the last interglaciation, however. In only the last 5-6 ka, multiple cycles of erosion and deposition occurred along the Holocene coastlines of the Bahamas (Hearty and Kaufman, 2000).

From a facies perspective, the Pe does not show a connection with its marine source beds above sea level. Its very fine eolian sediment texture is unlike that of any of the Be, De, or Southampton Formations. Deep and well-developed Hp soils are present on the Dm, indicating that a considerable amount of time passed before the deposition of the Pe.

Thus, I interpret the Pe not as an eolian facies of Dm as traditionally viewed, but as that of a subsequent highstand at $-10 \pm 5 \mathrm{~m}$ below present sea level, perhaps equivalent with MIS 5c. On the steep submarine slope adjacent to the South Shore study area, a $-10-\mathrm{m}$ shoreline would be positioned less than a few hundred meters offshore, and could thus provide sediments for wind transport above sea level. $\mathrm{Pe}$ is logically absent along the north coastline, because a $-10-\mathrm{m}$ shoreline in the north lagoon would be situated $10-15 \mathrm{~km}$ offshore. The position of MIS $5 \mathrm{c}$ sea level is supported indirectly by the cessation of growth of speleothems at $-6 \mathrm{~m}$ dated at ca. $100 \mathrm{ka}$ (Harmon et al., 1978). Sidescan mapping, uniboom surveys, and corals in growth position in the north lagoon at -10 to $-15 \mathrm{~m}$ also support this hypothesis (Vollbrecht, 1990), and U/Th ages from these corals fall between 105 and $97 \mathrm{ka}$.

\subsection{An early MIS 5e Belmont from a global perspective}

The reinterpretation of the stratigraphy of the South Shore of Bermuda puts the sea-level history in line with a more accepted view of sea level during MIS 5e and 7. Previously, the South Shore stratigraphy was impossible to correlate even with the North Shore of Bermuda, let alone with other key MIS 5e sites in the world. The height of the supposed MIS 7 Belmont at $+2.5 \mathrm{~m}$ (or the more extreme Meischner et al.'s, 1995 $+7.5-\mathrm{m}$ highstand), and its extensive outcropping was unlike any other of that age from tectonically stable localities. MIS 7 deposits in the Bahamas have typically consisted of scanty eolian and washover facies at sea level along the highest energy coastlines (Kindler and Hearty, 1996; Hearty, 1998), but reveal no emergent intertidal or subtidal deposits. Even in mildly uplifted Oahu, HI, Muhs and Szabo (1994) and Sherman et al. (1999) document a MIS 7 sea level stand between -10 and $-20 \mathrm{~m}$. With TIMS ages from a submerged stalagmite in Italy, Bard et al. (2002) constrained a peak MIS 7 sea-level highstand to a position between -18 and $-9 \mathrm{~m}$ between 202 and $190 \mathrm{ka}$.

Bermuda's tectonic setting and carbonate environment is closely compared with that of the Bahamas, where a highstand curve is evolving (Hearty and Kindler, 1995; Hearty, 1998; Hearty and Neumann, 2001). In North and South Carolina, and Oahu, HI, MIS $5 \mathrm{e}$ is also recognized by two major oscillations of sea level (Fig. 9) (Hollin and Hearty, 1990; Hearty et al., 2000). The first highstand peaked at $+2.5 \mathrm{~m}$ (corrected for lithospheric flexure in Oahu) between about 132 and $125 \mathrm{ka}$, based on the maximum height of in situ corals (Chen et al., 1991; Hearty and Kindler, 1993, 1998; Neumann and Hearty, 1996; White et al., 1998). The Belmont's $+2.5-\mathrm{m}$ highstand elevation agrees explicitly with that recognized during early MIS $5 \mathrm{e}$ in the Bahamas (Hearty and Kaufman, 2000; Hearty and Neumann, 2001). Sea-level movements during the Dm similarly conform with the latter part of MIS 5e during which sea level rose slowly at first, then quickly with brief halts at +6 and near $+9 \mathrm{~m}$ to form notches and rubble benches (Hearty and Neumann, 2001).

\subsection{Nomenclature}

The term "Belmont" has acquired so many meanings since Sayles (1931) that today it has virtually no meaning. The term should be summarily dropped from Bermuda's stratigraphic nomenclature and replaced with a new name reflecting its stratigraphic age and type locality. I suggest that the early last interglacial unit be informally named the Grape Bay member of the Rocky Bay Formation. The mapped area of the former Belmont, its type locality, and its name would represent the initial, stable highstand position of palaeo-sea level at $+2.5 \mathrm{~m}$ early in MIS 5e from $\sim 132$ to $\sim 125 \mathrm{ka}$. 
The name and interpretation of the Devonshire member remain unchallenged as the younger part of the Rocky Bay Formation. However, the Pembroke dune shows no facies connection with the Dm or the Rocky Bay Formation, and should therefore be distinguished from them. The existing Pembroke type area and name are unacceptable, as most or all of the north shore "Pembroke" dunes are either Be or De age. If they are indeed part of MIS $5 \mathrm{c}$, it is recommended that the Pe dunes be named the Hungry Bay Formation, where the Pe eolianite is best developed.

If MIS 7 deposits exist on Bermuda, the lower unit at Grape Bay RR and Harvey Road Quarry may possibly represent this interval. Mean whole-rock $A$ / $I$ ratios from these units of around 0.50 (Hearty and Vacher, 1994) are appropriate for a MIS 7 age. The "Belmont" highstand shoreline at $+7.5 \mathrm{~m}$ at Watch Hill Park, proposed by Meischner et al. (1995), is indefensible because neither a 200-ka age nor a + 7.5$\mathrm{m}$ highstand can be documented from the geology at Watch Hill Park.

At its type locality (Sayles, 1931), the Shore Hills geosol ( $\mathrm{SHg}$ ) is recognized as the Castle Harbour geosol, developed on the early Pleistocene Walsingham Formation. This soil is capped by the Upper Town Hill Formation of MIS 11 age (Hearty et al., 1992, 1999). The deep soil pipes at the type locality of $\mathrm{SHg}$ are never found on the South Shore, or associated with the $\mathrm{Bm} / \mathrm{Dm}$ contact; therefore, any reference to $\mathrm{SHg}$ in the context of the Belmont is inappropriate.

\section{Conclusions}

(1) The revision of the stratigraphy of the South Shore of Bermuda is based primarily on the diagnostic field characteristics of the Belmont and Devonshire deposits, their soils, and the boundaries separating them. The absence of a true, glacial-age red soil and accompanying weathered surface on the Belmont are the most persuasive evidence in this revision. A lens of red colluvium, washed from neighboring middle Pleistocene hillsides, was probably misinterpreted as a glacial soil.

(2) The Belmont Formation, as mapped along the South Shore between Grape Bay and Watch Hill Park, is the result of an early MIS 5e transgression that peaked at $+2.5 \pm 0.3 \mathrm{~m}$ between 132 and $125 \mathrm{ka}$.
This age and highstand elevation is directly supported by ca. $125 \mathrm{ka} \mathrm{U}$-series ages from $+3-\mathrm{m}$ notch fillings around the island.

(3) The difference in mean $A / I$ ratios ( $A / I 0.08$ to 0.15 ) between Belmont and Devonshire deposits can be explained by the exponential rate increase of epimerization caused by $10-15 \mathrm{ka}$ of warm interglacial climate during MIS 5e. Previous interpretations of the aminostratigraphy did not consider the profound impact of interglacial warmth on epimerization rate.

(4) Reconsideration of the stratigraphy of South Shore Bermuda has revealed evidence favoring a younger interpretation of the Belmont Formation. The postulated extensive nature of MIS 7 Belmont deposits, and the near absence of MIS 5e Devonshire deposits along the low-lying South Shore of Bermuda creates a paradox. A revised early MIS 5e interpretation of the Belmont resolves this paradox, and places the stratigraphy of Bermuda in line with the global view of these distinctively different MIS 5e and 7 sea level events. A type locality and the new name "Grape Bay Member of the Rocky Bay Formation" is proposed.

(5) With evidence of a mid-5e regression (advance of Sabal colonization on intertidal and subtidal deposits, and the late rise of sea level during the Devonshire), Bermuda may now be considered one of the premier global localities demonstrating a double sealevel highstand during MIS 5e.

\section{Acknowledgements}

I am grateful to J. Hollin, P. Kindler, S. Olson and others who helped to develop the concepts in this paper. This manuscript was greatly improved by energetic and constructive reviews by C.V. MurrayWallace (U. Wollongong, Australia) and A. Strasser (U. Fribourg, Switzerland). Logistical and financial help in Bermuda was provided by a grant from the Bermuda Aquarium, Museum, and Zoo (W. Sterrer, Director). This is contribution \#48 to the Bermuda Biodiversity Project, and to IGCP Project 437 "Coastal Environmental Change During Sea-level Highstands".

Full colour versions of the illustrations (Figs. $1,2,3,4,5,6,8)$ can be obtained from the author by email request. 


\section{References}

Bard, E., Antonioli, F., Silenzi, S., 2002. Sea-level during the penultimate interglacial period based on a submerged stalagmite from Argentarola Cave (Italy). Earth Planet. Sci. Lett. 6096, $1-12$.

Bretz, J.H., 1960. Bermuda: a partially drowned late mature Pleistocene karst. Geol. Soc. Amer. Bull. 71, 1729-1754.

Bricker, O.P., Mackenzie, F.T., 1970. Limestones and red soils of Bermuda, discussion. Geol. Soc. Amer. Bull. 81, 2523-2524.

Chappell, J., Shackelton, N.J., 1986. Oxygen isotopes and sea level. Nature 324, 137-140.

Chen, J.H., Curran, H.A., White, B., Wasserburg, G.J., 1991. Precise chronology of the last interglacial period: ${ }^{234} \mathrm{U} /{ }^{230} \mathrm{Th}$ data from fossil coral reefs in the Bahamas. Geol. Soc. Amer. Bull. 103, 82-97.

Cortijo, E., Lehman, S., Keigwin, L., Chapman, M., Paillard, D., Labeyrie, L., 1999. Changes in meridional temperature and salinity gradients in the North Atlantic Ocean $\left(30^{\circ}-72^{\circ} \mathrm{N}\right)$ during the last interglacial period. Paleoceanography 14 (1), 23-33.

Hare, P.E., Mitterer, R.M., 1967. Non-protein amino acids in fossil shells. Carnegie Inst. Washington, Year Book 65, 236-364.

Harmon, R.S., Schwarcz, H.P., Ford, D.C., 1978. Late Pleistocene sea level history of Bermuda. Quat. Res. 9, 205-218.

Harmon, R.S., Mitterer, R.M., Kriausakul, N., Land, L.S., Schwarcz, H.P., Garrett, P., Larson, G.J., Vacher, H.L., Rowe, M., 1983. Useries and amino acid racemization geochronology of Bermuda: implications for eustatic sea-level fluctuation over the past 250,000 years. Palaeogeogr. Palaeoclimatol. Palaeoecol. 44, $41-70$.

Hearty, P.J., 1986. An inventory of last interglacial (s.1.) age deposits from the Mediterranean basin: a study of isoleucine epimerization and U-series dating. Z. Geomorphol., Suppl. Bd. 62, 59-61.

Hearty, P.J., 1987. New data on the Pleistocene of Mallorca. Quat. Sci. Rev. 6, 245-257.

Hearty, P.J., 1997. Boulder deposits from large waves during the last interglaciation on North Eleuthera, Bahamas. Quat. Res. 48, 326-338.

Hearty, P.J., 1998. The geology of Eleuthera Island, Bahamas: a Rosetta Stone of Quaternary stratigraphy and sea-level history. Quat. Sci. Rev. 17, 333-355.

Hearty, P.J., Aharon, P., 1988. Amino acid chronostratigraphy of late Pleistocene coral reef sites: Huon Peninsula, New Guinea and the Great Barrier Reef, Australia. Geology 16 (7), 579-583.

Hearty, P.J., Dai Pra, G., 1992. The age and stratigraphy of Quaternary coastal deposits along the Gulf of Taranto (south Italy). J. Coast. Res. 8 (4), 882-905.

Hearty, P.J., Kaufman, D.S., 2000. Whole-rock aminostratigraphy and Quaternary sea-level history of the Bahamas. Quat. Res. 54, $163-173$.

Hearty, P.J., Kindler, P., 1993. New perspectives on Bahamian geology: San Salvador Island, Bahamas. J. Coast. Res. 9 (2), 577-594.

Hearty, P.J., Kindler, P., 1995. Sea-level highstand chronology from stable carbonate platforms (Bermuda and the Bahamas). J. Coast. Res. 11 (3), 675-689.
Hearty, P.J., Kindler, P., 1997. The stratigraphy and surficial geology of New Providence and surrounding islands, Bahamas. J. Coast. Res. 13, 798-812.

Hearty, P.J., Kindler, P., 1998. Comment on White et al. (1998) "Bahamian coral reefs yield evidence of a brief sea-level lowstand during the last interglacial". Carbonates Evaporites 13 (2), 229-230.

Hearty, P.J., Miller, G.H., 1987. Global trends in isoleucine epimerization: data from the circum-Atlantic, the Mediterranean and the south Pacific. Geol. Soc. Am. Annu. Meet., Abstr. Programs, 698.

Hearty, P.J., Neumann, A.C., 2001. Rapid sea-level and climate change at the close of the Last Interglaciation (MIS 5e): evidence from the Bahama Islands. Quat. Sci. Rev. 20, 1881-1895.

Hearty, P.J., Vacher, H.L., 1994. Quaternary stratigraphy of Bermuda: a high-resolution pre-Sangamonian rock record. Quat. Sci. Rev. 13, 685-697.

Hearty, P.J., Vacher, H.L., Mitterer, R.M., 1992. Aminostratigraphy and ages of Pleistocene limestones of Bermuda. Geol. Soc. Amer. Bull. 104, 471-480.

Hearty, P.J., Neumann, A.C., Kaufman, D.S., 1998. Chevron ridges and runup deposits in the Bahamas from storms late in oxygen isotope substage 5e. Quat. Res. 50, 309-322.

Hearty, P.J., Kindler, P., Cheng, H., Edwards, R.L., 1999. Evidence for a $+20 \mathrm{~m}$ middle Pleistocene sea-level highstand (Bermuda and Bahamas) and partial collapse of Antarctic ice. Geology 27, $375-378$.

Hearty, P.J., Kaufman, D.S., Olson, S.L., James, H.F., 2000. Stratigraphy and whole-rock amino acid geochronology of key Holocene and Last Interglacial carbonate deposits in the Hawaiian Islands. Pac. Sci. 54 (4), 423-442.

Hearty, P.J., Tormey, B.R., Neumann, A.C., 2002. Discussion of "Palaeoclimatic significance of co-occurring wind- and waterinduced sedimentary structures in the last-interglacial coastal deposits from Bermuda and the Bahamas" (Kindler and Strasser, 2000. Sed. Geol. 131, 1-7). Sediment. Geol. 147, 429-435.

Hollin, J.T., Hearty, P.J., 1990. South Carolina interglacial sites and stage 5 sea levels. Quat. Res. 33, 1-17.

Kindler, P., Hearty, P.J., 1996. Carbonate petrology as an indicator of climate and sea-level changes: new data from Bahamian Quaternary units. Sedimentology 43 (2), 381-399.

Kindler, P., Strasser, A., 2000. Palaeoclimatic significance of cooccurring wind- and water-induced sedimentary structures in the last-interglacial coastal deposits from Bermuda and the Bahamas. Sediment. Geol. 131, 1-7.

Kindler, P., Strasser, A., 2002. Palaeoclimatic significance of cooccurring wind- and water-induced sedimentary structures in the last-interglacial coastal deposits from Bermuda and the Bahamas: a response to Hearty et al.'s comment. Sediment. Geol. 147, 437-443.

Land, L.S., Mackenzie, F.T., Gould, S.J., 1967. The Pleistocene history of Bermuda. Geol. Soc. Amer. Bull. 78, 993-1006.

Ludwig, K.R., Muhs, D.R., Simmons, K.R., Halley, R.B., Shinn, E.A., 1996. Sea-level records at $\sim 80 \mathrm{ka}$ from tectonically stable platforms: Florida and Bermuda. Geology 24 (3), 211-214.

Mackenzie, F.T., 1964. Bermuda Pleistocene eolianites and paleowinds. Sedimentology 3, 51-64. 
Meischner, D., Vollbrecht, R., Wehmeyer, D., 1995. Pleistocene sealevel yo-yo recorded in stacked beaches, Bermuda South Shore. Geol. Soc. Spec. Pap. 300, 295-310.

Miller, G.H., Magee, J.W., Johnson, B.J., Fogel, M.L., Spooner, N.A., McCulloch, M.T., Ayliffe, L.K., 1999. Pleistocene extinction of Genyornis newtoni: human impact on Australian megafauna. Science 283, 205-208.

Muhs, D.R., Szabo, B.J., 1994. New uranium-series ages of the WaimanaloLimestone, O'ahu, Hawai'i: implications for sea level during the last interglacial period. Mar. Geol. 118, 315-326.

Munsell, 1994. Soil Color Charts (revised edition) Macbeth Division of Kollmorgan Instruments, New Windsor, NY 12553.

Murray-Wallace, C.V., Belperio, A.P., 1991. The last interglacial shoreline in Australia-a review. Quat. Sci. Rev. 10, 441-461.

Neumann, A.C., Hearty, P.J., 1996. Rapid sea-level changes at the close of the last interglacial (stage 5e) recorded in Bahamian Island geology. Geology 24, 775-778.

Rowe, M.P., 1998. An explanation of the Geology of Bermuda: Bermuda Ministry of the Environment, 2nd ed. Hamilton, Bermuda, $28 \mathrm{pp}$.

Sachs, J.P., Lehman, S.J., 1999. Subtropical North Atlantic temperatures 60,000 to 30,000 years ago. Science $286,756-759$.

Sayles, R.W., 1931. Bermuda during the Ice Age. Am. Acad. Arts Sci. 66, 381-468.

Shackleton, N.J., Opdyke, J.N., 1973. Oxygen isotope and paleo- magnetic stratigraphy of equatorial Pacific core V28-238: oxygen isotope temperatures and ice volumes on a $10^{5}$ and $10^{6}$ year time scale. Quat. Res. 3, 39-45.

Shackleton, N.J., Berger, A., Peltier, W.R., 1990. An alternative astronomical calibration of the lower Pleistocene time scale based on ODP site 677. Trans. R. Soc. Edinb. Earth Sci. 81, $251-261$.

Sherman, C.E., Fletcher, C.H., Rubin, K.H., 1999. Marine and meteoric diagenesis of Pleistocene carbonates from a nearshore submarine terrace, Oahu, Hawaii. J. Sediment. Res. 69 (5), $1083-1097$.

Vacher, H.L., Hearty, P.J., 1989. History of stage-5 sea level in Bermuda: with new evidence of a rise to present sea level during substage 5a. Quat. Sci. Rev. 8, 159-168.

Vacher, H.L., Rowe, M., Garrett, P., 1989. Geologic map of Bermuda: Oxford Cartographers, U.K. 1:25,000 scale.

Vacher, H.L., Hearty, P.J., Rowe, M.P., 1995. Stratigraphy of Bermuda: nomenclature, concepts, and status of multiple systems of classification. Geol. Soc. Am. Spec. Pap. 300, 269-294.

Vollbrecht, R., 1990. Marine and meteoric diagenesis of submarine Pleistocene carbonates from the Bermuda carbonate platform. Carbonates Evaporites 5, 13-95.

White, B., Curran, H.L., Wilson, M.A., 1998. Bahamian coral reefs yield evidence of a brief sea-level lowstand during the last interglacial. Carbonates Evaporites 13 (1), 10-22. 